\title{
Educating Antiracist Lawyers: The Race and the Equal Protection of the Laws Program at Dickinson Law
}

Dermot M. Groome

Penn State Dickinson Law, dmg32@psu.edu

Follow this and additional works at: https://ideas.dickinsonlaw.psu.edu/fac-works

Part of the Legal Education Commons, and the Legal Profession Commons

\section{Recommended Citation}

Dermot M. Groome, Educating Antiracist Lawyers: The Race and the Equal Protection of the Laws Program at Dickinson Law, Forthcoming Rutgers Race \& L. Rev. (2021). been accepted for inclusion in Faculty Scholarly Works by an authorized administrator of Dickinson Law IDEAS. For more information, please contact lja10@psu.edu. 


\title{
DRAFT as of June 29, 2021
}

Forthcoming in the Rutgers Race and the Law Review

Please do not cite until this article is in final form

\section{EDUCATING ANTIRACISTS LAWYERS: The Race and the Equal Protection of the LaWs Program}

\author{
Dermot Groome ${ }^{1}$
}

\begin{abstract}
The killing of George Floyd forced the nation to recognize painful realities about systemic racism in our country and our legal system. The deficiencies in our founding documents and the vestiges of our slaveholding past are so woven into our national culture that they became hard to see except for those who suffer their daily indignities, hardships, and fears. The collective experience of watching Floyd's murder made these undeniably and viscerally visible to all Americans. As legal educators, we must face the role we have played in helping build the machinery of structural racism by supplying generation after generation of those who maintain that machinery and prosper within it. In this critical moment of our country's history, we, as legal educators, must train and prepare a generation of lawyers to complete once and for all the work of the Civil Rights Movement, a Third Reconstruction and to purge racism from our legal system - to build better safeguards to ensure that all people have the equal protection of the laws promised by the 14th Amendment of our Constitution.

As educators, we have a unique opportunity and important responsibility to combat racism in our educational mission. We must do more than transfer legal knowledge and skills to our students. We must cultivate within them a principled, enduring commitment to work for true equality over the course of their careers and to practice law in a way that promotes
\end{abstract}

${ }^{1}$ Professor Dermot Groome is the Harvey A. Feldman Distinguished Faculty Scholar at Penn State Dickinson Law. Prior to joining the faculty, he led the prosecution of five international criminal trials at the International Criminal Tribunal for the former Yugoslavia (ICTY), including the Bosnia indictment against Slobodan Milošević and the case against General Ratko Mladić. Groome began his career as a prosecutor in the Manhattan District Attorney's Office. Prior to joining the UN, Groome worked for over eight years in the fields of human rights and community development in Kingston, Jamaica and Cambodia. 
the equal treatment of all. To do this, we must reconsider not only what we teach, but how we teach it.

This article sets out one possibility. It describes the Race and Equal Protection of the Laws program at Penn State Dickinson Law. ${ }^{2}$ It describes a teaching method I developed for the task of teaching students about the relationship between race and our legal system. It describes how over 50 students, faculty and alumni worked together to create the substantive content of the course. This innovative program draws upon the principles of Critical Pedagogy to develop an educational approach with the objective of transforming how our students see their place and role in our flawed, evolving democracy. It incorporates the literature of different scholars commonly referred to as Critical Race Theorists to help students recognize the indicia of structural racism and better understand its root causes.

The structure and methods used in the program guide students towards a deepened consciousness of the relationship between race and our legal system and why, despite its mostly neutral language, it still facilitates and maintains a system that results in Americans of different colors have different lived experiences. It encourages students to identify problems that can be addressed by lawyers and explores with them sources of law and justice that can be brought to bear on the problem. Finally, it shares with students the "Story and Vision" of lawyers who can speak authoritatively and authentically about the areas of law we examine and invites students to develop their own carefully considered response as lawyers.

During this yearlong course, students have examined the relationship between race and our legal system in the following areas: housing, health care, criminal justice, democracy, capitalism, and education. Future iterations of the course will broaden this coverage and examine other types of inequality in our legal system.

\footnotetext{
${ }^{2}$ For a video describing the program and a webinar explaining its methodology that includes the reactions from students see, https://dickinsonlaw.psu.edu/race-and-the-equal-protection-of-the-laws
} 


\section{EDUCATING ANTIRACISTS LAWYERS: The Race and the Equal Protection of THE LAWs Program}

[Y] ou have received a great education. You must leave here and go out and get in the way. When you see something that is not right, not fair, not just, you must have the courage to stand up, to speak up and find a way to get in the way.

John Lewis (1940-2020) $)^{3}$

\section{TABLE OF CONTENTS}

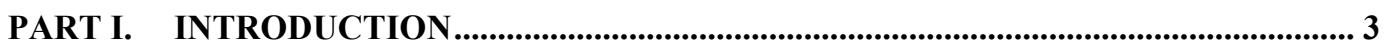

PART II. THE TEACHING METHOD_........................................................................ 9

PART III. SUMMARY OF THE REPL SESSIONS .........................................................35

PART IV. CONCLUSION ....................................................................................................

\section{Part I. Introduction}

For over 400 years, the history and legacy of slavery have permeated American life. In eight minutes in 2020, the curtain on this legacy of racial injustice fell away, laying bare the depths of the injustices visited upon Blacks and People of Color. ${ }^{4}$ The death of George Floyd has caused a reckoning for us as lawyers, to accept that the profession to which we have devoted our lives has been an essential component in the machinery of structural racism. As legal educators, we must face our role in building that machinery and supplying the generations of lawyers who maintain it, perpetuate it, and prosper within it.

\footnotetext{
${ }^{3}$ Valerie Strauss, The Prescient Commencement Speech Rep. John Lewis Gave in 2016, THE WASH. Post (Jan. 16, 2017), https://www.washingtonpost.com/news/answer-sheet/wp/2017/01/16/the-prescientcommencement-speech-rep-john-lewis-gave-in-2016/

${ }^{4}$ Associated Press, Prosecutors Say Officer Had Knee on George Floyd's Neck for 7:46 Rather than 8:46, L.A. TIMES (June 18, 2020), https:/www.latimes.com/world-nation/story/2020-06-18/derek-chauvin-hadknee-george-floyd-neck-746-rather-than-846
}

DRAFT - DO NOT CITE 3 of 71 
On June 2, 2020, the Faculty of Penn State Dickinson Law unanimously adopted a resolution recognizing "the ongoing, systemic and perpetual racial and societal injustices in this country, which have been passed on from generation to generation." The faculty jointly resolved that "we must never enable but should all be active antiracists in taking responsibility to condemn and to end" systemic racism wherever it exists. ${ }^{5}$ On June 18, 2020, the Faculty unanimously adopted a resolution that I drafted entitled "Race and Our Educational Mission," This second resolution was my attempt to operationalize the faculty's resolution to be antiracist. This second resolution recognized that the Faculty had "a unique opportunity and important responsibility to combat racism and inequality through its educational mission." ${ }^{6}$ In this document, the Faculty resolved to

\section{Penn State Dickinson Law Faculty, Faculty Resolution (2020),} https://dickinsonlaw.psu.edu/sites/default/files/2020-06/faculty-resolution.pdf.

The full paragraph setting out the resolute commitment of the faculty states:

NOW, THEREFORE, BE IT RESOLVED that the faculty acknowledges that racism is an affliction that we must never enable but should all be active antiracists in taking responsibility to condemn and to end, that we need to identify and challenge systemic prejudice wherever it exists, that we are all accountable for doing the work necessary for policy changes that dismantle structural systems of oppression that perpetuate racial inequities in our society, that we will strive to be better listeners and supporters of those who are the victims of racism, that we will never rest until every American feels safe, free and accepted in our country, and that we will continuously abide by the goal of providing respect and equal treatment to all in upholding the rule of law.

${ }^{6}$ Penn State Dickinson Law Faculty, Race And OuR EduCAtional Mission (2020), https:/dickinsonlaw.psu.edu/sites/default/files/2020-07/Race-and-Our-Educational-Mission.pdf.

\section{RACE AND OUR EDUCATIONAL MISSION}

RECALLING, that on June 2, 2020, the faculty of Penn State Dickinson Law unanimously adopted a resolution recognizing "the ongoing, systemic and perpetual racial and societal injustices in this country, which have been passed on from generation to generation;" and committed itself to "continuously abide by the goal of providing respect and equal treatment to all in upholding the rule of law;" and

RECALLING, that in December 2012, the faculty adopted, as one of its core principles, a commitment "to improve global understanding and the lives and well-being of our students and the world in which they will live;" and

RECOGNIZING, that as a law faculty, Penn State Dickinson Law has a unique opportunity and important responsibility to combat racism and inequality through its educational mission.

The faculty of Penn State Dickinson Law herein resolves to incorporate more opportunities for students to learn about and discuss racism and inequality in the curriculum. The faculty further resolves to develop and require students to participate in 
develop an annual plan of anti-racist education throughout its curriculum, to develop cocurricular programing addressing structural racism, and to conduct a yearly assessment of the effectiveness of its efforts. By these two resolutions, Dickinson Law has incorporated antiracist education into its core educational mission, a commitment that "shall remain in effect until such time that the faculty deems, by resolution, that it is no longer necessary."7 Other law schools have taken similar actions. For example, the deans of all ten law schools in Texas have committed: "to equip these future generations of attorneys with the ability to recognize injustice, including racial injustice - and the commitment to advocate for its eradication." 8

At the same time I proposed we adopt Race and Our Educational Mission, I presented the faculty with a blueprint for a co-curricular program called Race and the Equal Protection of the Laws ("REPL"). This document proposed that, in addition to incorporating issues of race wherever relevant in our curriculum, all students be required

co-curricular programs that instill in students an abiding appreciation of, and eagerness to defend, the Equal Protection Clause of the 14th Amendment of the U.S. Constitution and to cultivate within students, a principled, enduring commitment to work for true equality in our society over the course of their careers.

Further, to fully implement this resolution, the faculty shall require the Diversity Committee or other committee designated by the Dean:

1. to develop and present an annual plan for the implementation of this resolution at the second faculty meeting of each academic year;

2. to present a written report before the last faculty meeting of the academic year, summarizing the curricular and co-curricular activities undertaken that year and assessing their effectiveness; and

3. to conduct a detailed study evaluating the implementation of this resolution every five years, commencing at the end of the 2024-25 academic year.

This resolution shall remain in effect until such time that the faculty deems, by resolution, that it is no longer necessary.

Adopted this 18th day of June, 2020, by the unanimous vote of Penn State Dickinson Law

${ }^{7} I d$.

8 Brad Toben, Michael Barry, Patricia Roberts, Jennifer Collins, Robert Ahdieh, Jack Nowlin, Joan Bullock, Leonard Baynes, Ward Farnsworth \& Felicia Epps, Statement of The Deans of the Ten Texas Law Schools Condemning Racism and Remembering George Floyd, THE UNIV. OF TEX. AT AUSTIN SCH. OF L. (June 10，2020), https:/law.utexas.edu/news/2020/06/10/statement-of-the-deans-of-the-ten-texas-law$\underline{\text { schools/. }}$ 
to participate in a program that explored the relationship between race and our legal system and engaged the in constructive diverse conversations about this relationship. The proposal set out in nascent form, a unique teaching method that I believed was required by the subject matter and our objective to cultivate within students an enduring commitment to work for equality as lawyers. ${ }^{9}$ The faculty unanimously approved the REPL program.

Starting in the fall of the 2020-21 academic year, the REPL program became a required course for all first-year students. ${ }^{10}$ This one-credit, eight-session course examines the relationship between race and our legal system and how the implementation of mostly race-neutral laws have shaped and perpetuated structural racism in areas like criminal justice, education, health care, housing, capitalism and in our democratic institutions. The final session of the course redirected the focus of the discussions to the students themselves. Students were asked to begin the process of discerning what their individual response might be as lawyers at this moment of our country's history. We challenged students to imagine how they, as lawyers, might dismantle systems of racism and encouraged them to make a solemn, personal commitment to themselves do so. Students were invited to record a video selfie of their personal commitment to themselves as a reminder for the future when professional and personal obligations may compete with their resolve to work for equality as lawyers. ${ }^{11}$

\footnotetext{
${ }^{9}$ Penn State Dickinson Law School FACUlty, supra note 6.
}

10 Although the program is required for first-year students, upper-level students and our candidates for Master's and Doctorate degrees were also be able to attend. Some faculty required students in their upperlevel courses to attend specific sessions (e.g., students enrolled in Business Entities were required to attend the session on Capitalism and Commercial Law).

The University of Chicago Law School offers a pre-orientation program to first year students that includes a lecture on Critical Race Theory. See Pre-Orientation Program, The UnIV. Of CHI.: THE L. ScH. https://www.law.uchicago.edu/law-school-pre-orientation-program (last accessed Mar. 8, 2021).

\footnotetext{
${ }^{11}$ Professor Deborah Archer, president of the ACLU described the course in her remarks as the program being "really revolutionary in legal education." Deborah Archer, Race and Democracy (Apr. 7, 2021) (recording on file with the author).
} 
A diverse group of over fifty individuals, including faculty, staff, upper-level students, and alumni, have worked together to pool their knowledge, personal experiences, and skills to create the content of the program, give presentations to students and guide them in the sometimes difficult conversations we have asked them to have with each other. Recognizing the importance of role models, REPL also invites lawyers who can speak authoritatively and authentically about the issues examined in the course.

The two resolutions of the Dickinson Law Faculty recognize that our responsibility as legal educators is not simply to transfer legal knowledge and skills, but to "instill in students an abiding appreciation of, and eagerness to defend, the Equal Protection Clause of the 14th Amendment of the U.S. Constitution and to cultivate within students, a principled, enduring commitment to work for true equality in our society over the course of their careers." 12 To do this, we must not only reconsider what we teach but how we teach it.

The rationale underlying the Equal Protection Clause is succinctly stated in Constance Baker Motley and Thurgood Marshall's complaint in Brown v. Board of Education: "This case deals with inequalities imposed on individuals by the state, because of race. The Fourteenth Amendment was passed to abolish these inequalities."13 Motley, known as the "civil rights queen," ${ }^{14}$ secured James Meredith's right to attend the University of Mississippi. She represented Dr. Martin Luther King Jr. and the Freedom Riders and, as the first Black woman to appear before the Supreme Court, won nine of the ten cases she argued. ${ }^{15}$ Motley became the first Black woman to be appointed to the

\footnotetext{
${ }^{12}$ Penn State Dickinson Law School Faculty, supra note 6.

13 Complaint at 2, Brown v. Board of Educ., 98 F. Supp. 797 (D. Kan. 1951) (Civ. No. T-316), https://www.docsteach.org/documents/document/complaint-in-brown-v-board-of-education-of-topeka.

${ }^{14}$ See Tomiko Brown-Nagin on Constance Baker Motley and the 'American Experience', HARV. L. TODAY (Aug. 18, 2016), https://today.law.harvard.edu/tomiko-brown-nagin-constance-baker-motley-americanexperience/.

${ }^{15} I d$.
} 
federal bench, where she presided over many civil rights cases during her 36 years as a judge. ${ }^{16}$ It was as a judge that Motley struggled with the complexities of applying the limited power of "the equal protection of the laws" to ensure real equality in the lived experience in the lives of Black and Brown people. She issued decisions that both surprised and disappointed civil rights lawyers. ${ }^{17}$

The five words of the Clause derive their immense import from their brief but unequivocal mandate - they correct the hypocrisy of our founders' assertion that "all men are created equal." In essence, the Equal Protection Clause is a call to, and a guarantee of, equality for all; it is a call for legal and social justice for all people under the jurisdiction of the United States. The challenge before us as educators is to train lawyers who will become agents for the promotion and protection of equality within our legal system. It is not enough to simply expect race-neutral laws; we must train lawyers committed to interpreting and applying those laws in a manner that ensures real equality in the lived experience of all Americans.

This article describes the first iteration of the REPL program. We are in the process of assessing its successes and failures and will adapt and improve the program in the coming years so that we can best prepare our students for the difficult work awaiting them. Part II of this essay describes the teaching method I developed for this course. A method that relies heavily on the principles of Critical Pedagogy. Next, Part III presents an overview of the teaching method developed for REPL and informed by Critical Pedagogy. It describes how we structure each session of REPL in order to help transform how law students see their opportunities and responsibilities as lawyers with respect to equality. Part IV provides a summary of the eight sessions of the course, and Part V offers some closing thoughts on this project.

\footnotetext{
${ }^{16}$ Tomiko Brown-Nagin, Identity Matters: The Case of Judge Constance Baker Motley, 117 CoLUM. L. REV. 1691, 1697-98 (2017).

${ }^{17} I d$.
} 


\section{Part II. The Teaching Method}

Central to the REPL program is its teaching method. REPL considers that how we teach is as important as what we teach. REPL's goal is not only to impart important substantive knowledge regarding the relationship between race and our legal system but help students consider what kind of lawyer they will become when they become part of that legal system. In order to discharge our second resolution's mandate to "cultivate within students, a principled, enduring commitment to work for true equality in our society over the course of their careers," we must strive for more than providing them with relevant information. Rather, we must engage students in considering how the 14th Amendment calls them to practice law in their intended practice area - perhaps a lesson to which those who trained us as law students were insufficiently attentive. When our students take their oaths of admission to the bar, they must appreciate what their commitment to "support, obey and defend the Constitution of the United States" and the equal protection it guarantees requires of them throughout their legal careers. To do this, REPL has developed a unique teaching method and structure that incorporates principles of Critical Pedagogy and aspires to change how they see their role as lawyers.

\section{Critical Pedagogy}

Critical Pedagogy, developed by Paulo Freire, is an educational theory that arose out of the social justice movements in South America in the 1960s. These movements, which paralleled our own Civil Rights Movement, sought to ameliorate the systemic injustices suffered by indigenous and historically oppressed peoples. Critical Pedagogy's essential insight is the idea that a goal of education should be to create an "opportunity for students to be able to reflectively frame their own relationship to the ongoing project of an unfinished democracy." 18

In the 1980s, Thomas Groome, working in the field of religious education, took the secular educational principles of Critical Pedagogy and applied them in a structured teaching approach for religious educators. His Shared Christian Praxis Approach

\footnotetext{
${ }^{18}$ Henry A. Giroux, On Critical Pedagogy (2nd ed. 2020).
} 
("Shared Praxis") has been used widely for over 40 years and throughout many cultures and contexts; it recognizes that the most effective way to teach a faith tradition is to do so in the context of the shared experience of that faith community. It also holds that teaching of faith traditions should inform and help shape each person's own response to the world and situation in which they find themselves. The teaching method that I developed for the REPL program incorporates principles from Critical Pedagogy and is informed by Shared Praxis'structured approach to implementing Critical Pedagogical principles.

Critical Pedagogy calls us as legal educators to include in all our courses the opportunity for students to reflect on our nation's shared experience of the area of the law under consideration and to help students "reflectively frame their own relationship" to it. Criminal law and criminal procedure courses fail students if they omit an examination of the law's disparate impact on different communities. Courses on commercial law, housing law, health law, and education law should meaningfully engage with students about our nation's shared experience of the disparate impact of the law in these areas and encourage students to consider how the law might change and how they, as lawyers, might practice their profession in a way that promotes true equality. Coursework should not be insulated from what is happening in our country but fully immersed in it so that students not only learn settled principles of law and theory but understand their unique opportunities and responsibilities to address societal problems as lawyers.

In light of recent events, our students will look to us to help them make sense of the relationship between race and our legal system and to assist them in discerning how they might address these deeply rooted problems as lawyers. As educators, we must nurture their intuitions of justice so that they lead to life-long commitments. We must train students to be vigilant for inequalities in whatever corner of our legal system they ultimately work and prepare them to be guardians of true equality in all they do as lawyers.

Justice Robert Jackson, like Constance Baker Motley and Thurgood Marshall was one of our country's great lawyers. He is the only lawyer to have held the positions of Solicitor General (1938-40), Attorney General (1940-41) and Associate Justice of the US 
Supreme Court (1941-1954). After World War II, he was the chief architect and lead prosecutor of the Nuremburg Trials.

When Jackson finished his work in Nuremberg in 1946, he returned to the Supreme Court no doubt a different person, having confronted the architects of the Holocaust and the unspeakable horrors they wrought. Jackson knew in detail how the Nazis used law and the legal system as an instrument of oppression, persecution, and ultimately genocide. He saw how atrocities had their roots in the discriminatory laws that eventually became part of the machinery of the Holocaust. I also saw this phenomenon during my work as a UN prosecutor in the International Criminal Tribunal for the former Yugoslavia (ICTY). ${ }^{19}$

A few years after Jackson resumed his work as Associate Justice, the Court decided Railway Express Agency Inc., et al. v. People of the State of New York, which considered the permissibility of posting advertisements on the sides of buses in New York City. Despite the seeming triviality of the case's subject matter - bus advertising Jackson recognized that Railway Express Agency Inc. implicated the Equal Protection Clause of the 14th Amendment and was therefore of the utmost importance. In his concurring opinion in Railway Express Agency, Inc., no doubt informed by his work at

${ }^{19}$ In Bosnia and Herzegovina, the first indications of the atrocities to come were prosecutors' and judges' discriminatory application of neutral laws against Muslims and other targeted groups. This treatment took many forms, such as the selective enforcement of criminal, commercial, housing and education law and different readings of statutes depending on litigants' ethnicity. Over time, the biased interpretation of the law gave way to laws, decrees, and regulations that were explicitly discriminatory in their text and effect. In time there was a comprehensive system that removed Muslims and non-Serbs from their jobs; imposed special registration requirements and mandated special identification documents for Muslims; denied Muslims access to their bank accounts, removed their house phones, restricted their movement, and subjected some Muslims to daily searches of their homes and persons. Together, these measures culminated in a grave physical attack on the Muslim population involving crimes against humanity (persecution, murder, rape, forcible transfer, etc.) and in some cases genocide. See, e.g., Prosecutor v. Mladić, Case No. IT-09-92, Judgment, ๆๆ 1422-29 (Int'l Crim. Trib. for the Former Yugoslavia Nov. 22, 2017) (describing the persecutory legal regime established in the municipality of Prijedor, Bosnia and Herzegovina). 
Nuremburg, Jackson found that New York State could allow or prohibit advertising on buses, but it had to apply the law equally to everyone. In his concurrence, Jackson wrote:

This equality is not merely abstract justice. The framers of the Constitution knew, and we should not forget today, that there is no more effective practical guaranty against arbitrary and unreasonable government than to require that the principles of law which officials would impose upon a minority must be imposed generally. . . Courts can take no better measure to assure that laws will be just than to require that laws be equal in operation. ${ }^{20}$

Jackson appreciated the important protection the 14th Amendment provides against the misuse of our legal system to oppress or persecute some citizens. Our students must graduate law school attentive to the potential for our laws, devoid of explicit racist language, to be applied in a manner that perpetuates injustice and inequality. They must go forward with the firm resolve to engage in the practice of law in a manner that combats systemic racism and fosters equality. The REPL course endeavors to instill in our students this knowledge and resolve.

I do not suggest that there is only one way, or even a limited number of ways, for us as legal educators to train our students during these difficult times. ${ }^{21}$ In fact, some will find some aspects of the approach discussed below to be familiar. Rather, this essay invites all legal educators, stirred by recent events, to develop a shared understanding of how our legal system contributes to systemic racism; to investigate its root causes; to reacquaint ourselves with how, at times, our laws, legal traditions and great lawyers have been agents of equality; to reconsider the relationship between social justice and legal education; and finally, to find a response as educators that meets the gravity of the

\footnotetext{
${ }^{20}$ Ry. Express Agency, Inc. v. New York, 336 U.S. 106, 112 (1949) (Jackson, J., concurring).

${ }^{21}$ Over 20 U.S. law schools offer courses on Critical Race Theory or on racial justice. Schools offering courses and seminars on Critical Race Theory include: Berkeley, Columbia, Duke, Georgetown, Harvard, NYU, Northwestern, Stanford, UCLA, U. of Conn, U. of Chicago, U. of Michigan, U. Penn, and Yale.
} 
moment. This article my first modest attempt to do these things in the context of the REPL program.

Paulo Freire was born in Brazil in 1921 and grew up in poverty. He attended law school, and although he was admitted to the bar, he chose instead to teach secondary school in poor communities. While teaching literacy, Freire discovered that he could achieve better results when he taught students to become critically aware of social issues that impacted their lives. ${ }^{22}$ Beginning with some issue that was important to the peasant people of northeastern Brazil where he was teaching literacy (e.g., the need for decent housing), Freire discovered that they learned more readily to read and spell the term (casa) when it was associated with their social needs. This realization of the relationship between social consciousness and pedagogy led him to a careful study of the synergy between the two. Brazil's elites, threatened by a formerly silent and illiterate poor underclass who now could read and think about social issues, ended Freire's literacy program after a coup d'état by military leaders in 1964. Freire was imprisoned 70 days for treason before being released.

As an educator and philosopher, Freire thought deeply about the systemic inequality of Brazilian society and about how education might address it. His most famous work, Pedagogy of the Oppressed, sets out his understanding of the relationship between education and social change and how that understanding should inform the work of educators. Core to his theory is the notion that educators must help students "develop their power to perceive critically the way they exist in the world with which and in which they find themselves; they come to see the world not as a static reality, but as a reality in progress, in transformation." ${ }^{23}$ A student aware of their place in a reality capable of change by them, will, over time, discern their own role in that change. To Freire, the most

\footnotetext{
${ }^{22}$ In one of his experiments, Freire was able to teach 300 illiterate sugarcane harvesters to read and write in 45 days.
} 
effective way to nurture this process was not through a traditional pedagogy that "banked" information in the mind of students as if they were passive receptacles but through a Socratic-like dialogue with students. Freire emphasized the importance of a give-and-take, not simply about a topic of interest, but about an epochal generative theme, an important contemporary social issue that cried out for redress. Further, Freire proposed a dialogue in which participants, instructor and student alike, engage each other as co-investigators and critical thinkers in a reflective process, unmasking the reality and causes of oppression, and imagining how to be agents of social change. ${ }^{24}$

If Freire were alive at this moment, he undoubtedly would see systemic racism as a social injustice to be addressed with Critical Pedagogy. He would surely favor a pedagogy that recognizes the shared (not same) lived experience of both those advantaged and those disadvantaged by our legal system. He would propose to address injustice through a critically reflective dialogue between teacher and students about the relationship between race and our legal system, ${ }^{25}$ reasoning that the more active the

${ }^{23}$ Paulo Friere, Pedagogy of The Oppressed 83 (4th ed. 2018). "A deepened consciousness of their situation leads people to apprehend that situation as a historical reality susceptible of transformation." Id. at 84.

${ }^{24}$ Id. at 92 et seq.

[T]rue dialogue cannot exist unless the dialoguers engage in critical thinking - thinking which discerns an indivisible solidarity between the world and the people and admits of no dichotomy between them - thinking which perceives reality as process, as transformation, rather than as a static entity - thinking which does not separate itself from action, but constantly immerses itself in temporality without fear of the risks involved. Critical thinking contrasts with naïve thinking, which sees "historical time as a weight, a stratification of the acquisitions and experiences of the past," from which the present should emerge normalized and "well-behaved."

FREIRE, supra note 23, at 92 (quoting PIERRE FURTER, EDUCAÇÃO E VIDE 26z-27 (1966)).

${ }^{25} I d$ at 96.

Henry Giroux writes:

Freire was acutely aware that what makes critical pedagogy so dangerous to ideological fundamentalists, the ruling elites, religious extremists, and right-wing nationalists all over the world is that central to its very definition is the task of educating students to become critical agents who actively question and negotiate the relationships between theory and 
conversation and collaboration, the deeper students' understanding will be. Freire calls this deeper shared understanding conscientização. Roughly translated, conscientização is a critical consciousness that is disposed and determined to act for necessary change. ${ }^{26}$ Through this process of investigation and reflection, "[h] hmankind emerge from their submersion and acquire the ability to intervene in reality as it is unveiled." 27

Is Critical Pedagogy relevant to our time and to our task as educators at this moment? In a book chapter entitled "Critical Pedagogy in Dark Times," Henry A. Giroux, a Critical Pedagogy scholar, wrote:

It is hard to imagine a more urgent moment for making education central to politics. If we are going to develop a politics capable of awakening our critical, imaginative, and historical sensibilities, it is crucial for educators and others to develop a collective language of critique and possibility. Such a language is necessary to enable the conditions to forge a collective international resistance among educators, youth, workers, artists, and other cultural contributors in defense of public goods.... In an age of social isolation, information overflow, a culture of immediacy, consumer glut, and spectacularized violence, it is all the more crucial to take seriously the notion that a democracy cannot exist or be defended without informed and critically engaged citizens. ${ }^{28}$

practice, critical analysis and common sense, and learning and social change. Critical pedagogy opens up a space where students should be able to come to terms with their own power as critically engaged citizens; it provides a sphere where the unconditional freedom to question and assert one's convictions is made central to the purpose of public schooling and higher education, if not democracy itself.

GIROUX, supra note 18, at 181 .

${ }^{26}$ FREIRE, supra note 23, at 109. "Conscientização is the deepening of the attitude of awareness characteristic of all emergence." Id.

${ }^{27} I d$. at 109 (emphasis in the original).

${ }^{28}$ GIROUX, supra note 18, at 219. 
Critical Pedagogy recognizes that, as a precondition to becoming agents of social change, students must make the connection between knowledge and critical awareness; this effort must be "buttressed by a profound desire to overcome injustice and a spirited commitment to social action." 29

\section{The Teaching Method Used in REPL}

During his doctoral studies in education, Thomas Groome began to consider how the secular theory of Critical Pedagogy might be applied in his field of religious education. He was a student of Freire's work, and eventually they became colleagues, coteaching a graduate course in education. ${ }^{30}$ Groome's first book, Christian Religious Education, published in 1980, introduced what he called the Shared Christian Praxis Approach to religious education. ${ }^{31}$ Ten years later, he would publish Sharing Faith, the definitive statement of the Shared Praxis approach, which is an amalgam of the core principles of Critical Pedagogy and his own scholarly work in the field of religious education. $^{32}$

Shared Praxis divides each educational event that employs Critical Pedagogy into a series of five movements (i.e., moving forward in a process). With its clear structure and organization, Shared Praxis allows those with varying levels of training to employ

${ }^{29} I d$. at 224. Giroux goes further to say:

$[\mathrm{P}]$ olitical education foregrounds education guided not by the imperatives of specialization and professionalism, but by goals designed to expand the possibilities of democracy. Linking education to modes of political agency is therefore part of a larger project to promote critical citizenship and address the ethnical imperative to alleviate human suffering.

${ }^{30}$ I became familiar with Freire's and Groome's work when I audited this course and attended a number of lectures while I was in law school. Thomas Groome is my uncle.

31 Thomas H. Groome, Christian Religious EduCAtion: SHARING OUR Story and ViSiOn (1980).

32 Thomas H. Groome, Sharing Faith: A Comprehensive Approach to Religious EdUCATION AND PAStORAl Ministry (1991). Groome most succinctly describes Shared Praxis as "bringing life to faith and faith to life." See Diocese of Ballarat Cath. Educ. Ltd., Thomas Groome: Understanding Shared Christian Praxis, YouTuBE (July 16, 2018), https://www.youtube.com/watch?v=DnWFKBR2Rhk. 
effectively Critical Pedagogy's principles. Shared Praxis is widely used today by both university professors and part-time Sunday school teachers; it has been adopted by Jewish and Islamic educators and has also been adapted for use in a number of secular fields. Critical Pedagogy informed by the structured approach of Shared Praxis provide useful tools for any educator who strives to help students understand their full capacity to shape their world. ${ }^{33}$ The structure and methods used in REPL have incorporated and is informed by both Critical Pedagogy and Shared Praxis to help us better serve students who wonder how they can be proactively antiracist, both as lawyers and as ordinary citizens. In addition to sharing knowledge about the relationship between race and our legal system, REPL aspires to serve as a catalyst for transformative personal reflections by students about their responsibility to fight racism as lawyers.

\section{OVERVIEW OF THE TEACHING METHOD USED IN REPL}

Each of the eight sessions of REPL is designed with a four-part structure. Each of the four elements works with the others to guide students to a deeper understanding of an important issue and helps them develop their own response as laywers.

Selecting a Generative Theme for Individual Classes

The first task in designing the REPL course was to identify the theme on which we would focus in each of the eight sessions. For assistance, we looked to Freire's concept of the generative theme. Generative themes, as defined by Freire, are, by their very nature, important life issues that are likely to engage participants' interest. According to Freire, a generative theme arises from the situation bounded by the time and place in which students find themselves. Groome describes the generative theme as, "some historical issue - question, value belief, concept, event, situation and so on - that is likely to draw participants into active engagement because it has import and meaning

\footnotetext{
${ }^{33}$ Over the years, I have used an adapted version of Shared Praxis when training human rights investigators in Cambodia and lawyers in the former Yugoslavia. I have also used elements of it in my human rights seminar and for particular topics in criminal law such as the death penalty.
} 
for their lives." 34 There are race-related generative themes in many doctrinal law classes. For instance, students could consider the relationship between race, structural racism and property law, contract law, criminal law, banking law, education law, health law, etc. For this first iteration of the course, I selected seven generative themes related to race and our legal system. The last session did not focus on a generative theme but refocused on the students themselves and their own capacity to be agents of change as lawyers.

Generative themes can exist in concentric circles moving from the general to the particular. ${ }^{35}$ The generative themes of our program include both broad issues related to our entire legal system and more focused examinations of particular areas of the law. In our first session, Historic and Modern Privilegia, we started with the broadest possible focus, the outermost circle of possible themes, by examining the foundational documents of our country and the various laws that have created structural advantages for some and structural disadvantages for others.

The next six sessions were built around more granular generative themes. In these sessions, we addressed important areas of the law that have daily, significant impacts on us all. These generative themes (capitalism, criminal justice, housing, health care, education, and democracy) are all important dimensions of American life and impact the lives of students.

Element One: Turning our Attention to the Issue

Every REPL session begins with a Focusing Activity. The Focusing Activity establishes the curriculum for the session around a generative theme. Here, the intent is twofold: a) to engage students as active participants in an interactive teaching/learning dynamic, and b) to focus students on the generative theme of the class. "The focusing activity turns people to their own 'being' in place and time, to their present praxis, and

\footnotetext{
${ }^{34}$ GROOME, supra note 32, at 156.

${ }^{35}$ FREIRE, supra note 23, at 103.
} 
establishes a focus for the curriculum." 36 The specific form the focusing activity can be broad, provided it effectively prepares students to engage with the learning content that follows. The key is to establish the session's theme as vital, urgent, and deserving of attention.

In REPL we use a two-part Focusing Activity. The first is the Playlist. One week before the actual session, students receive a playlist of multi-media links to help them prepare for the session. These links have directed students to podcasts, music videos, speeches, poetry readings, short readings, and works of art. The items are chosen because they will engage students with the theme, present them with perspectives that may be different from their own, and begin the process of thinking about their lived experience with respect to that theme. In the session on Capitalism, for instance, we included a link to a National Public Radio program that examined how Department of Agriculture policies forced many Black farmers from their land. For the Criminal Justice session, we included a slam poem about a Black man talking to his nephew as the police approach the car they are both in. Students who listen to the Playlist arrive at the session prepared to thoughtfully immerse themselves in the issue.

The second part of the Focusing Activity, which begins the class session itself, is called "Turning our Attention to the Issue." Rather than introduce the issue in lecture format, we introduce it with a compelling video or story that shifts students from their busy day to a sharp focus on the generative theme of the class. In our first session on Historic and Modern Privilegia, our focusing activity was a six-minute film depicting young descendants of Frederick Douglass reading excerpts of "What to the Slave Is the

${ }^{36}$ GROOME, supra note 32, at 146 . Groome goes further:

Typically, it does this most effectively by engaging participants with shared focus in a generative theme for the teaching/learning event. It may do this by sponsoring a present action of it or by turning them toward some aspect of their historical reality in the world to recognize the theme as it is operative in present praxis.

Id. at 146. 
Fourth of July," a speech Douglass gave on July 5, 1852. ${ }^{37}$ In Race and Criminal Justice, a second-year student described an encounter he and his brother had with police officers when he was eight years old.

Element Two: The Lesson

After the Turning our Attention to the Issue segment, we move to the Lesson element. In developing this course, I thought - how can we engage students in a critical reflection on race and our legal system when they, like me, probably do not know our own history in sufficient detail to have an informed discussion about it? In this segment, members of the faculty and upper-level students give a series of presentations designed to provide essential information about the generative theme. A session typically includes five or six ten-minute sessions. Each is a concise exposition of the generative theme. It is not intended as a comprehensive treatment of the subject. ${ }^{38}$ In addition to providing important information about a specific aspect of the issue, we endeavor to trace modern phenomena to the Antebellum period. For example, in the Capitalism session, we began with a discussion of the slave market on Wall Street, in the heart of our country's financial district; we then moved to slave mortgages, the history of "40 acres and a mule," the New Deal, and redlining; and we ended the lesson with a presentation on the impediments Black-owned businesses faced in accessing Payroll Protection Payments (PPP) during the COVID-19 pandemic.

Element Three: Small Group Discussions

After completing the Lesson segment, students gather in small groups to discuss a prompt. The groups are made intentionally diverse and are moderated by a member of the faculty and an upper-level student. The moderator's primary role is to help create a safe

${ }^{37}$ See VIDEO: Frederick Douglass' Descendants Deliver His 'Fourth of July' Speech NPR (July 3, 2020, 5:05 AM), https://www.npr.org/2020/07/03/884832594/video-frederick-douglass-descendants-read-hisfourth-of-july-speech.

38 These short presentations are supplemented by a more complete treatment of the subject matter in an essay written by the presenter and included in the handout for that session. They are also supplemented by more exhaustive treatment of these topics in different courses offered in our curriculum. 
place for complex and difficult discussions about race. We structure these discussions and provide prompts designed to achieve two important goals of Critical Pedagogy: a) naming the generative theme and b) critical reflection on that theme.

\section{Naming the Generative Theme}

One of the objectives in the discussions is to engage students in a dialogue or activity designed to develop a shared common understanding of the issue - their "present praxis." Groome writes that "to engage people's 'present praxis' in a pedagogical event is to turn them to the consciousness that emerges from and the agency expressed in their whole way of 'being' as 'agent-subjects-in-relationship' in place and time, that is, to reflect on whatever is 'being done' by them, from them, through them and is 'going on' around them, to them, and to others in their sociocultural context." ${ }^{39}$ Freire describes the pedagogical intent here as enabling people to speak their own word, to "speak their truth" as they see it.

Freire was convinced that only by first "naming the world" can people begin to change it. During this element, the instructor recognizes the validity of the students' experience of the world (in this instance, the ways in which our legal system has advantaged and/or disadvantaged them) and, in a dialogue with students, creates a shared understanding of the theme. This is not to say that students will have a common shared experience of the law, just that they will develop a shared understanding of their different experiences. In the Housing Session, for instance, students discussed their different lived experience of housing and developed a shared understanding of race and housing that incorporated their different individual experiences. During the sessions, participants are encouraged to express their own perception of their relationship to the issue, how they feel about it, and how the issue is reflected in their own unique socio-cultural context.

${ }^{39}$ GROOME, supra note 32, at 134. 


\section{Critical Reflection}

Once students reach a relatively common understanding of the issue/problem, we engage them in an activity designed to facilitate critical reflection on the subject. The goal of reflection in this situation is to achieve a deeper understanding of the theme by examining it socio-culturally - in other words, contextually, historically, politically, economically, etc. ${ }^{40}$ Critical reflection can engage reason, memory, and/or imagination, or any combination thereof, and can be both personal and socio-cultural. This element "enables participants to come to a critical appropriation of present praxis in their 'place' and 'time' and metaphorically, to share in dialogue their own 'stories' and 'visions'."41

In the context of Historic and Modern Privilegia, students were asked to reflect on whether or not the Constitution has lived up to the promises in its preamble. In Race and Housing, students developed a ten-year plan to encourage greater integration in the local community. Students engaged in such a cooperative exercise must necessarily draw from some of the material presented in The Lesson, reflect on the group's shared experience of race and housing, and develop strategies designed to respond to the generative theme in their particular time and place.

Students can engage in an examination of the history of our legal system (i.e., the Constitution, the Fugitive Slave Acts, Jim Crow, voting laws, cash bail and excessive fines); the lived experiences of those impacted differently by our laws; and the biases/prejudices embedded in our legal system's architecture. Moderators can pose the questions of the Critical Race theorists about why the promise of the Civil Rights Movement and its legal victories before the Supreme Court have not translated into fundamental changes in the lived experience of Blacks and other People of Color. Is it as

\footnotetext{
40 Groome writes, "The intent is to deepen the reflective moment and bring participants to a critical consciousness of present praxis: its reasons, interests, assumptions, prejudices, and ideologies (reason); its sociohistorical and biographical sources (memory); its intended, likely, and preferred consequences (imagination). See GROOME, supra note 32, at 147.

${ }^{41} I d$.
} 
Alan Freeman first suggested in 1978, that "in its core concept of the 'violation,' antidiscrimination law is hopelessly embedded in the perpetrator perspective?"42 Put another way, is antidiscrimination law largely indifferent to the lived experience of victims of inequality and "merely [intended] to neutralize the inappropriate conduct of the perpetrator"? ${ }^{43}$ What role did Washington v. Davis (concerning the equal protection component of the Due Process Clause) play in reordering the relationship between discriminatory effects and discriminatory intent and in requiring that claimants establish the latter? ${ }^{44}$ As Aziz Huq has observed, "[ $\left.\mathrm{t}\right]$ he granular ways of implementing grand, abstract ideas such as 'discriminatory intent' turn out to be highly consequential on the ground." ${ }^{45}$ Is Huq correct? Or is Davis best explained by Derrick Bell's interestconvergence theory that asserts that Black progress is only tolerated by the White majority when it aligns or convergences with a matter of White interest? ${ }^{46}$

Although REPL does not attempt to address Critical Race Theory (CRT) comprehensively, one of its objectives is to introduce its students to some of CRT's core concepts and principles. We recognize that future iterations of the course might be improved by a more deliberate effort to instruct students in some CRT concepts. In this

\footnotetext{
42 Alan Freeman, Legitimizing Racial Discrimination Through Antidiscrimination Law: A Critical Review of Supreme Court Doctrine, 62 MiNN. L. REV. 1049, 1053 (1978).

${ }^{43} I d$.

44 Washington v. Davis, 426 U.S. 229, 240 (1976). In Washington v. Davis, the Supreme Court held that "the invidious quality of a law claimed to be racially discriminatory must ultimately be traced to a racially discriminatory purpose." Id. For a discussion of the intent requirement on the Equal Protection Clause see Stephen Rinehart, Proving Intentional Discrimination in Equal Protection Cases: The Growing Burden of Proof in the Supreme Court, 10 N.Y.U. REV. L. \& Soc. CHANGE 435 (1981)

45 Aziz Huq, What is Discriminatory Intent?, 103 CoRnELL L. REV. 1211, 1291 (2018). Huq catalogues the definitional and practical difficulties that those claiming a violation of equal protection or establishment clause face.

46 See Derrick Bell, Brown v. Board of Education and the Interest-Convergence Dilemma, 93 HARV. L. REV. 518, 523-28 (1980).
} 
first iteration, we have included a primer on CRT in one of the handouts and have invited two CRT scholars to give presentations to students on education and health care from a CRT perspective. CRT has engaged in critical reflection on race and our legal system for decades, and its methods and the questions it poses inform our choice of prompts and activities for the small group discussions.

Critical Race Theory

The CRT movement began in the 1970s as scholars recognized that the advances made during the Civil Rights Movement had slowed, stopped, and in some respects "were being rolled back." 47 The potential for improving the lived experience of Blacks promised by favorable precedents such as Brown v. Board of Education were diminished by lower court decisions that narrowed their implications and by administrative and bureaucratic "slow rolling" of their mandate. ${ }^{48}$ Similarly, the Supreme Court's ruling in

47 Richard Delgado \& Jean Stefancic, Critical Race Theory 3-4 (3d ed. 2018). Delgado summarizes Critical Race Theory as:

The critical race theory (CRT) movement is a collection of activists and scholars engaged in studying and transforming the relationship among race, racism, and power. The movement considers many of the same issues that conventional civil rights and ethnic studies discourses take up but places them in a broader perspective that includes economics, history, setting, group and self- interest, and emotions and the unconscious. Unlike traditional civil rights discourse, which stresses incrementalism and step- by- step progress, critical race theory questions the very foundations of the liberal order, including equality theory, legal reasoning, Enlightenment rationalism, and neutral principles of constitutional law.

Id. Over time, CRT principles and approaches have also been used in the study of the relationship between other identifiable groups and structures of power. These include Asian Americans, Latinos, LGBT people, Muslims, and Native Americans.

${ }^{48}$ Delgado \& Stefancic, supra note 47, at 5. See also, Bell, supra note 46, at 518. See also Mario L. Barnes, "The More Things Change ... ": New Moves for Legitimizing Racial Discrimination in a "PostRace” World, 100 MinN. L. REV. 2043, 2082-83 (2016) (footnotes omitted):

The history of race relations in America is neither a narrative of undisturbed linear progress nor that of a stable phenomenon that remains unchanged. Slavery was followed by a period of de jure discrimination where formal exclusionary social practices during Reconstruction, such as Jim Crow and the Black Codes, ultimately resulted in racial segregation in most important areas of social life. Even though civil unrest, litigation 
Shelby County v. Holder rendered largely ineffective the legislative accomplishment of the Voting Rights Act of 1965.49

Early theorists such as Derrick Bell, Alan Freeman, and Richard Delgado challenged the triumphalist narrative of Civil Rights jurisprudence, adopting a more realistic assessment of its actual gains and positing the rise of subtler forms of racism. ${ }^{50}$ Bell attributed these advancements to White self-interest, ${ }^{51}$ while Freeman asserted that despite their apparent liberal thrust, the lasting impact of these cases was a legitimization of racism. ${ }^{52}$ Some theorists asserted that the legal victories of the Civil Rights Movement, in fact, impeded social change through a process of co-optation, "a process by which the focus on legal reform narrows the cases, deradicalizes the agenda, legitimizes ongoing injustices, and diverts energies away from more effective and transformative

victories, such as Brown v. Board of Education, and landmark civil rights legislation pared back formal methods of exclusion, racism continues to flourish.

49 Shelby Cnty., Ala. v. Holder, 570 U.S. 529, 553 (2013). Chief Justice Roberts writing, for the majority held that "[o]ur country has changed, and while any racial discrimination in voting is too much, Congress must ensure that the legislation it passes to remedy that problem speaks to current conditions." Id. at 577.

Beginning in 2014, the Congress has tried several times to enact new legislation that updates the Voting Rights Act of 1965 and corrects the infirmities identified in Shelby. The most recent effort, The Voting Rights Advancement Act of 2019, has languished without being brought to the floor for a vote in the Senate. See Marianne Levine, McConnell Won't Allow Vote on Election Reform Bill, PoLITICO (Mar. 6, 2019), https://www.politico.com/story/2019/03/06/mcconnell-election-reform-bill-1207702. an even more recent attempt is the For the People Act (see https://www.cnn.com/2021/03/17/opinions/voting-rightspolitical-miracle-stacey-abrams/index.html).

50 Delgado \& StefanciC, supra note 47, at 4. Other principal figures using Critical Race Theory to investigate the lived experience of Blacks: Paul Butler, Devon Carbado, Kimberlé Crenshaw, Lani Guinier, Angela Harris, Cheryl Harris, Charles Lawrence, Mari Matsuda, Angela Onwuachi-Willig, and Patricia Williams.

${ }^{51}$ See Bell, supra note 46, at 524-25.

${ }^{52}$ Freeman, supra note 42 , at 1053. 
alternatives." 53 Critical Race Theory adopted and adapted analytical methods and concepts used by scholars working in critical legal studies and radical feminism. ${ }^{54}$

The work of scholars in critical legal studies and CRT provides an indispensable framework for any critical reflection with students on the generative theme, and the variety of thought in the field offers a number of perspectives from which to coinvestigate a generative theme with students. While the REPL course currently has modest teaching objectives with respect to CRT, we recognize that as the course evolves over the years, we must train ourselves and our students in understanding the relationship between race and our legal system using some of the tools of CRT in our analysis and discussions.

Critical Race theorists typically align themselves with one of two groups of theorists: idealists and realists. Idealists hold that racism is a function of thought and categorization - a social construction. Realists hold that racism consists of the societal structures that apportion benefits and burdens; on this view, education, health care, housing, etc. are distributed according to a racial hierarchy. ${ }^{55}$ In Race and Housing, Kate Walz, a senior litigator with the National Housing Project expertly explained how Chicago's zoning laws and the Aldermanic Prerogative have perpetuated a hierarchical, generation-spanning system of segregated housing. ${ }^{56}$

The view a particular CRT theorist holds determines the solutions they ultimately propose. For idealists, effective solutions to address racism include diversity training, speech codes, and positive media role models. ${ }^{57}$ For realists, progress requires structural

53 Orly Lobel, The Paradox of Extralegal Activism: Critical Legal Consciousness and Transformative Politics, 120 HarV. L. ReV. 937, 939 (2007).

${ }^{54}$ Delgado \& STEFANCIC, supra note 47, at 4-5.

${ }^{55} \mathrm{Id}$. at 7.

${ }^{56}$ Kate Walz, A City Fragmented: How Race, Power, and Local Control Shape Chicago’s Neighborhoods (Jan. 27, 2021) (recording on file with author).

${ }^{57}$ DELGADO \& STEFANCIC, supra note 47, at 25. 
changes to institutions such as the criminal justice system, unions, etc. ${ }^{58}$ Within these broad categories of thought there are different themes that are a useful source for instructors as they design a structured dialogue for critical reflection with their students. The major themes are described below.

\section{The Ordinariness of Racism}

Racism is an ordinary part of America's social and power structures. Societal structures and our legal system routinely and systemically advantage Whites over Blacks and other non-Whites. ${ }^{59}$ The "ordinariness" of racism cloaks it with an invisibility that makes it hard to address and allows it to persist within a legal system containing facially neutral laws. ${ }^{60}$ During the Group Discussion element, moderators and students can work as co-investigators to better understand this phenomenon of structural racism's ordinariness and "invisibility." Were there aspects of the generative theme of which students were not previously conscious? Why was a student from the dominant group unable to see what may have always been clear to students of Color? Some feedback from both Black and White students suggests that the lessons coupled with group discussion have helped students to see how our legal system advantages and disadvantages Americans according to their race. As a result, students have an emerging understanding of a phenomenon that was previously unseen by them.

\footnotetext{
${ }^{58} I d$.

${ }^{59}$ Isabel Wilkerson likens these ordinary ubiquitous structures to a caste system not unlike other historical caste systems. See ISABEL WiLKerson, CASte, THE ORIGINS OF OUR DisCONTENTS (2020).

${ }^{60} \mathrm{Id}$. at 8. Professor Mario L. Barnes, in an update to Alan Freeman's influential article, Legitimizing Racial Discrimination Through Antidiscrimination Law: A Critical Review of Supreme Court Doctrine (1978), writes that "the endorsement of America as truly post-race has freed up the [Supreme] Court to move beyond the issues Professor Freeman noted, toward an even stingier conception of equality." Barnes, supra note 48, at 2053.
} 


\section{Racial Hierarchies and Interest-Convergence}

Realists hold the view that racism is the system that American society uses to allocate benefits and burdens. ${ }^{61}$ Blacks are only allowed to advance within American society when doing so converges with White self-interest (e.g., economic interests). Bell called this "interest-convergence." 62 Racism provides advantages to Whites and neutralizes incentives to eradicate structural racism. ${ }^{63}$ Does interest-convergence facilitate a deeper understanding of the generative theme? What is the White interest that is promoted through a perceived improvement to the lived experience of Blacks? Have traditionally White institutions of higher learning benefitted their own interests by giving greater access to Black students?

Interest convergence provides a powerful method through which students can critically reflect on important judicial decisions. Are watershed opinions best explained by interest convergence? Are inconsistent rulings better understood through the lens of interest convergence?

\section{Race as a Social Construction}

Idealists see the concept of race itself as a social construct disconnected from any objective biological, genetic or inherent basis. On this view, "race" is a socially constructed category that is used to gain, manipulate, and maintain power. ${ }^{64}$ For example,

\footnotetext{
${ }^{61}$ Delgado \& STEFANCIC, supra note 47, at 21.

${ }^{62}$ Bell writes:
}

“[T]his principle of 'interest convergence' provides: The interest of blacks in achieving racial equality will be accommodated only when it converges with the interests of whites...[T]he fourteenth amendment, standing alone, will not authorize a judicial remedy providing effective racial equality for blacks where the remedy sought threatens the superior societal status of middle and upper class whites.

Bell, supra note 46, at 523.

${ }^{63}$ Delgado \& STEFANCIC, supra note 47 , at 8.

${ }^{64}$ Id. See also EdUARDo BonIlla-SILVA, RACISM WITHOUT RACISTS: COLOR-BLIND RACISM AND THE Persistence of Racial Inequality in America (3d ed. 2009); Critical Race TheOry: The Key 
the Jim Crow era's "one-drop rule" defined persons with a single African ancestor as "negro" irrespective of their being perceived as White by others. ${ }^{65}$ If attitudes of race are constructed, then they can be deconstructed by identifying and changing the images, texts and social teachings used to construct them. ${ }^{66}$ What social constructions are involved in the generative theme? How have these messages shaped students' views of race and our legal system? How does our legal system reinforce these constructs? In Race and Health Care, we consider the case of a Black medical doctor who contracted COVID-19 and was denied pain medicines she knew she needed because of biases on the part of the White hospitalist assigned to treat her.

\section{Revisionist History}

Some Critical Race idealists focus their lens on American history. Careful scrutiny of the widely accepted historical narrative reveals inaccuracies that embed racist notions of non-Whites in the dominant group. Older school textbooks and westerns are good examples of a historically inaccurate record glorifying White Europeans' conquering of so-called "savages" and omitting accurate historical facts such as the Trail of Tears. Revisionist history scrutinizes the American historical narrative by comparing it with evidence of other contrary narratives. Scholars in this field seek to "replac[e] comforting majoritarian interpretations of events with ones that square more accurately

Writings that Formed the Movement (Kimberlé Crenshaw, Neil Gotanda, Gary Peller \& Kendall Thomas eds., 1995).

${ }^{65}$ As the poet Langston Hughes wrote:

You see, unfortunately, I am not black. There are lots of different kinds of blood in our family. But here in the United States, the word "Negro" is used to mean anyone who has any Negro blood at all in his veins. In Africa, the word is more pure. It means all Negro, therefore black. I am brown.

Langston Hughes, The Big Sea, in The Collected Works of Langston Hughes 36 (Arnold Ramersad ed., 2001). See also Neil Gotanda, A Critique of Our Constitution Is Color-Blind, 44 Stan. L. Rev. 1, 24 (1991).

${ }^{66}$ DeLGADO \& STEFANCIC, supra note 47 , at 20-21. 
with minorities' experiences." 67 Dickinson Law is a few miles from the site of the Industrial Indian School of Carlisle (now the U.S. Army War College). The school was home to hundreds of Native American children who were taken from their families in a systematic effort to strip them of their cultural identity and practices and "reform" them according to a European-centric notion of what constituted an American citizen. In Race and Education, we provided students with the information necessary to critically evaluate the Industrial Indian School and its impact on native American families and communities. What historical narratives have played a role in the shared understanding of the generative theme? How might students' understanding of a phenomenon be different if the historical narrative were an accurate and balanced one reflecting the different perspectives of those involved?

\section{Intersectionality}

The concept of intersectionality recognizes that each individual is likely to hold a composite identity that aggregates the variety of their physical and personality traits. A wealthy LGBTQ Black woman, for instance, cannot be defined by reference to any one aspect of her personhood, and sometimes different coexisting, overlapping identities can conflict and implicate contradictory allegiances. ${ }^{68}$ Issues of intersectionality should also be explored to the extent that the generative theme implicates them. Questions that hypothetically consider a person's parsed-out identities separately and are then contrasted with that person's lived experience can deepen an understanding of each identity's individual impact as well as their combined impact. This first iteration of REPL has not incorporated a discussion of intersectionality, but the faculty recognizes the need to incorporate this concept in future years. Some faculty have already begun to discuss how best to approach this important issue.

\footnotetext{
${ }^{67} I d$.

${ }^{68}$ DELGAdo \& STEFANCIC, supra note 47 , at 10-11.
} 


\section{Critique of Liberalism}

Many liberal thinkers, unaware of the slavery's continuing legacy, would espouse equal treatment under the law without regard to personal history and situation. Chief Justice John Roberts exemplified this liberal thinking when he wrote that " $[\mathrm{t}]$ he way to stop discrimination on the basis of race is to stop discriminating on the basis of race." 69 This statement fails to recognize that the legacy of slavery and systemic racism changes life's "starting line" and introduces inherent obstacles for Blacks and People of Color. Critical Race Theory recognizes that equal treatment under the law in some cases may prevent new inequities but still fails to address historic inequities in need of a remedy. ${ }^{70}$ What does fairness require for Blacks, who in some situations still bear historical burdens? Is it possible to strike a balance that addresses historical inequities without creating new inequities for individual members of the dominant group? CRT theorists consider recent Supreme Court decisions that are intolerant of corrective race considerations simply as calcifying and preserving an inequitable system. ${ }^{71}$ Students discussed the issue of reparation in several of the sessions. In Race and Capitalism, a third-year student demonstrated how wealth, first generated through the exploitation of Blacks, has remained in families with a slave-owning past. ${ }^{72}$

${ }^{69}$ Parents Involved in Cmty. Schs. v. Seattle Sch. Dist. No. 1, 551 U.S. 701, 748 (2007).

${ }^{70}$ Delgado \& StefanciC, supra note 47, at 27. As Professor Crenshaw points out:

Race consciousness also reinforces whites' sense that American society is really meritocratic and thus helps prevent them from questioning the basic legitimacy of the free market. Believing both that Blacks are inferior and that the economy impartially rewards the superior over the inferior, whites see that most Blacks are indeed worse off than whites are, which reinforces their sense that the market is operating "fairly and impartially; those who should logically be on the bottom are on the bottom.

Kimberlé Williams Crenshaw, Race, Reform, and Retrenchment: Transformation and

Legitimation in Antidiscrimination Law, 101 HARV. L. REV. 1331, 1380 (1988).

${ }^{71}$ Delgado \& Stefancic, supra note 47, at 27.

${ }^{72}$ Samantha Jacques, The Backbone of the American Economy (Oct. 29, 2020) (recording on file with author). 


\section{Sharing Critical Reflections}

All of the small group prompts involve some activity in which students must engage as a group and produce a collective work product. This has included joint internet-type reviews, development plans, or advice to a client. Students upload these to an online drop box so that their work product can be shared with the rest of the class. In Historical and Modern Privilegia, we invited groups to appoint a reporter to share the group's work in a plenary session. While this worked well and may be the ideal way of sharing critical reflections, it was deemed unworkable over the entire course because of the time constraints of a two-hour session.

Element Four: The Story and Vision

While the Small Group discussion is a collaborative process, a featured speaker takes center stage in the Story and Vision segment. In this element, the pedagogical task is to tell the story of how the law has addressed, does address, and can address the generative theme as now developed. For this element, we invite a prominent lawyer or activist who can speak both authoritatively and authentically on the subject. For example, Professor Deborah Archer, the new president of the ACLU, addressed the students during the session on Race and Democracy.

The task of the featured speaker is to guide students with clarity and accuracy through the ways our laws have and can be brought to bear to address inequality. During the Story and Vision element, students should be "awakened" to the power of the law to address inequality. Their understanding of the relationship between the issue and the relevant law should deepen, seeing the law as a powerful tool to combat inequality.

The story of the law also includes a candid retelling of its failures, where it has fallen short of ensuring equality, or when it has been an accomplice in the oppression of Blacks and people of Color. Again, the sources of law and justice from which the instructor may draw are varied.

Featured speakers are encouraged to share their vision for how we as lawyers and the law itself can be used for change. In Race and Housing, Kate Walz spoke to students about "Movement Lawyering" and how she seeks to use her skills as a lawyer to supplement, support, and advance constructive social movements working for greater 
equality. ${ }^{73}$ Dean Conway's address to students spoke of a "new era of Reconstruction" in which lawyers must reimagine their roles to pierce through dualities embedded within the American legal system. ${ }^{74}$

The Story and Vision segment presents students with an explicit invitation to consider the implications of what they have learned so far for their own lives, their lives now as law students, and their lives ultimately as lawyers. This element invites students to consider how their emerging understanding of the law calls them to act differently, to see themselves differently, and to see those they interact with differently - all toward greater equality and justice. It is an opportunity to make decisions about how they will engage the world in their unique time and place, using their personal talents and legal training to address more forcefully and equitably the issue presented in the generative theme. What is their response as lawyers to the issue? What will they do to promote greater justice and equality? Their response can be "primarily or variously cognitive, affective, and behavioral and may pertain to the personal, interpersonal, or sociopolitical levels of their lives." 75

Students' responses must be unique to the individual student and encourage personal actions and commitments to change their current behavior in order to promote greater equality. Ideally, the session will increase students' vigilance in opposing inequality and impart a sense of obligation to address inequality in their legal careers. REPL does not advocate that students should adopt any particular response and does not require to students to voice what their response might be. Each student's and lawyer's response is the product of their own discernment - a process for which the autonomy and privacy of the individual is respected in the REPL program.

\footnotetext{
73 Kate Walz, A City Fragmented: How Race, Power, and Local Control Shape Chicago's Neighborhoods (Jan. 27, 2021) (recording on file with author).

74 Danielle Conway, The Duality Between What We Know and What We Should Know About Democracy, Law and the Legal System in America (Sept. 24, 2020) (recording on file with author).

75 DELGADO \& STEFANCIC, supra note 47, at 148.
} 
At the start of the year, students received a reflection sheet, a diary-type form where they could record their impressions and thoughts regarding the individual sessions as well as their emerging sense of what kind of lawyer they aspire to be. They are encouraged to be honest and detailed in this document and are assured that they will never be required to share it. This inward-looking discernment process will culminate in the last session of the course. During this session, students were invited to begin their own discernment process and consider making a commitment to themselves to work for equality as a lawyer in their own way. Although students were not required to share their own emerging sense of self, as lawyers, some did and shared their aspirations for their career with other students and group moderators.

The Handout

Each session is accompanied by a Handout, which includes original essays and reprinted excerpts. The Handout is not the typical handout an instructor might prepare for a class. Rather, the Handouts are more akin to book chapters and serve more ambitious objectives than class handouts. Their first goal is to supplement The Lesson segment of the session. As previously described, The Lesson segment includes a series of short, concise expositions on some aspect of the theme. Most of the presenters prepare original essays that supplement their presentation. These essays describe the presenters' main points in greater detail and include citations and additional resources to help interested students explore particular topics in greater detail.

The Handout also provides students with relevant case law, excerpted articles, book chapters, historic speeches, and other materials designed to facilitate a deep, thoughtful exploration of the generative theme. There is no expectation that the students read the entire Handout prior to the session, but it is our hope that they will keep it and return to it in the future to continue learning about these issues and to consider their response as lawyers. 


\section{Part III. Summary of the REPL Sessions}

In this part, I will summarize each of the eight sessions of the program to illustrate REPL's the teaching method and the substantive material covered.

Session 1: Historic and Modern Privilegia

The first session of the program, Historic and Modern Privilegia, provided an overview of how our legal system has created disadvantages for some groups and advantages for others throughout our history. The term Privilegia is from Roman Law. The Second Edition of Black's Law Dictionary defines a Privilegium as "[a] special constitution by which the Roman emperor conferred on some single person some anomalous or irregular right, or imposed upon some single person some anomalous or irregular obligation, or inflicted on some single person some anomalous or irregular punishment." ${ }^{76}$ The word is used in this context is to describe those aspects of our overall legal system that create systemic advantages and disadvantages based on race.

A week prior to the session, students received a playlist with suggestions regarding material they could listen to or watch in preparation for the upcoming topic. For this first session, the playlist included, inter alia, a public address by Chief Justice Cheri Beasley of the North Carolina Supreme Court addressing the killing of George

\footnotetext{
${ }^{76}$ Privilegium, Black's Law Dictionary (2d ed. 1910). Depending upon their impact on the individual, Privilegia were characterized as either "favorable" or "odious."
} 
Floyd; ${ }^{77}$ a podcast by Ibram X. Kendi; ${ }^{78}$ the Seven Stages of Grief, by UN Goodwill Ambassador and Slam poet, Emi Hamoud; ${ }^{79}$ and Billie Holiday’s Strange Fruit. ${ }^{80}$

We chose for our "Turning our Attention to the Issue" segment a seven-minute video of the descendants of Frederick Douglass reciting excerpts from one of his most well-known speeches, "What, to the Slave, Is the Fourth of July?" 81 The speech, given in 1852 during Independence Day celebrations, is an unvarnished statement about how Black Americans at the time saw the Fourth of July - not as a day to celebrate independence, but as a day to remember the injustices of enslavement. The video was created by National Public Radio, with the assistance of young adults and teens descended from Douglass who recite the speech. The continued relevance of the words contained in the speech is clear, and they spotlight the lack of progress made over the last 169 years. ${ }^{82}$ Alexa Anne Watson, the 19-year-old, third great-granddaughter of Douglass begins the recitation along with four other descendants of Douglass, the youngest being twelve years old. The following are excerpts from the speech:

77 Chief Justice Cheri Beasley, Special Announcement, FACEBOOK (June 2, 2020), https:/www.facebook.com/NCcourts/videos/chief-justice-beasley-june-2-2020-specialannouncement/251903529564824/.

78 Christian Burno, 5 Podcasts to Listen to If You Really Want to Know About Race in America, WBUR (June 5, 2020), https://www.wbur.org/artery/2020/06/05/podcasts-to-listen-to-about-race-america (click on No in Between towards the bottom of the page).

${ }^{79}$ Emi Mahoud, The Seven Stages of Grief, InSTAGRAM (June 18, 2020), Error! Hyperlink reference not valid..

${ }^{80}$ Billie Holiday, StRANGE Fruit (Commodore Records 1939).

${ }^{81}$ Frederick Douglass, Address to the Rochester Ladies' Anti-Slavery Society: What, to the Slave, Is the Fourth of July? (July 5, 1852), https://www.blackpast.org/african-american-history/speeches-africanamerican-history/1852-frederick-douglass-what-slave-fourth-july/.

${ }^{82}$ See VIDEO: Frederick Douglass' Descendants Deliver His 'Fourth of July' Speech, NPR (July 3, 2020, 5:05 AM), https://www.npr.org/2020/07/03/884832594/video-frederick-douglass-descendants-read-hisfourth-of-july-speech. 
Fellow-citizens, pardon me, allow me to ask, why am I called upon to speak here to-day? What have I, or those I represent, to do with your national independence? Are the great principles of political freedom and of natural justice, embodied in that Declaration of Independence, extended to us?

I am not included within the pale of this glorious anniversary! Your high independence only reveals the immeasurable distance between us. The blessings in which you, this day, rejoice, are not enjoyed in common. The rich inheritance of justice, liberty, prosperity and independence, bequeathed by your fathers, is shared by you, not by me. The sunlight that brought life and healing to you, has brought stripes and death to me. This Fourth of July is yours, not mine. You may rejoice, I must mourn.

After the recitation, there is a Coda in which Douglass' descendants are invited to share their reflections on what his speech means for our time. Douglass Washington Morris II, a fourth-generation grandson of Douglass, with a look of despair, says:

This is so extremely relevant with today's protests. He had a lot of hope especially for his age. I'm getting to the point in my life, I'm only 20 years old but I'm exhausted. Like I have these thoughts like, 'will we ever really get to this point?' or is this really something that we should actually spend our time fighting for?

Isidore Dharma Douglass Skinner, the fifteen-year-old, fourth-generation grandchild of Douglass concludes the reflection with words of hope:

Someone once said that pessimism is a tool of white oppression. I think that is true. I think in many ways we are still slaves to the notion that it will never get better. But I think that there is hope and I think that it's important that we celebrate Black joy and Black life and we remember that change is possible, change is probable, and that there's hope. 
The Lesson portion of the program included seven five-to-seven-minute presentations tracing our history and how our laws have created, and maintain, a system of structural advantage and disadvantage based on race. Professor Stan Brand began with an examination of our Constitution and how the United States Supreme Court relied on its text to find that enslaved Blacks were, by definition, not citizens entitled to the protections and benefits of our Constitution. ${ }^{83}$ Professor Brand observed that "no honest treatment of the subject of racial equality and justice under the law can proceed without acknowledging and understanding the textual basis established in our Constitution." 84 Brand concluded that the implications of our founding text "must be included in the discussion [of our legal system], not as a historical footnote, but as an exegesis for our continuing struggle." ${ }^{85}$ Samantha Jacques, a third-year student, continued the examination of our Constitution by examining how Article IV, Section 2, Clause 3 - the Fugitive Slave Clause - was the legal basis of the Fugitive Slave Acts of 1793 and 1850. ${ }^{86}$ The 1850 law imposed an obligation on all Americans to enforce the institution of slavery by enacting criminal sanctions on anyone aiding an escaped slave. ${ }^{87}$ During her presentation, Ms. Jacques discussed the work of Robert Morris, a Black lawyer in Boston who fought to prevent Blacks from being re-enslaved in the South. ${ }^{88}$

The third presentation examined Pennsylvania's historic characterization as an abolitionist state. Ryan Marr, a second-year student, took a closer look at the Quaker State's relationship to slavery. ${ }^{89}$ He described how the Pennsylvania Act of 1780 for the

\footnotetext{
${ }^{83}$ Stan Brand, The Constitution of the United States (Sept. 24, 2020) (recording on file with author).

${ }^{84} I d$.

${ }^{85} I d$.

${ }^{86}$ Samantha Jacques, Fugitive Slave Acts of 1793 \& 1850 (Sept. 24, 2020) (recording on file with author).

${ }^{87} I d$.

${ }^{88} I d$.

${ }^{89}$ Ryan Marr, Slaves in a Quaker State: Cumberland County and the Failure of Gradual Emancipation (Sept. 24, 2020) (recording on file with author).
} 
Gradual Abolition of Slavery did not free any of the approximately 6,000 enslaved people in the Commonwealth. ${ }^{90}$ The law instead mandated that children born into bondage be released only after they completed 28 years of work for their owners. ${ }^{91}$ Similarly, Professor Thomas Place addressed the common misperception that the Emancipation Proclamation ended slavery. ${ }^{92}$ Place pointed out that the Emancipation Proclamation only applied to the southern states in rebellion and not to the remainder of the Union. ${ }^{93}$ Therefore, over 800,000 people continued to be enslaved in the border states and in areas occupied by the Union Army. ${ }^{94}$ Place described how slavery would continue until abolitionists, joined by suffragettes, successfully advocated for the passage of the 13th and 14th Amendments. ${ }^{95}$

The Lesson then turned to the period of Reconstruction. Michaela Burgess, a second-year student, gave a presentation on the Black Codes and Jim Crow Laws. ${ }^{96}$ Professor Gary Gildin, who has litigated cases on behalf of the ACLU - including before the Supreme Court - gave an overview of how systemic discrimination in voting laws have denied and suppressed the voting rights of Black Americans. ${ }^{97} \mathrm{He}$ explained the Voting Rights Act of 1965 and how the Supreme Court's decision in Shelby County v. Holder (2013) eroded many of the fundamental protections of the Voting Rights Act. ${ }^{98}$

\footnotetext{
${ }^{90} I d$.

${ }^{91} I d$.

92 Thomas Place, Why a Constitutional Amendment Was Required Following Emancipation Proclamation (Sept. 24, 2020) (recording on file with author).

${ }^{93} I d$.

${ }^{94} I d$.

${ }^{95} I d$.

${ }^{96}$ Michaela Burgess, The Black Codes and Jim Crow Laws (Sept. 24, 2020) (recording on file with author).

${ }^{97}$ Gary S. Gildin, Finding the "System" in Systemic Discrimination in Voting (Sept. 24, 2020) (recording on file with author).

${ }^{98} I d$.
} 
Professor Raff Donelson, whose doctrinal work focuses on constitutional protections within the criminal justice system, presented on the disparate impact of cash bail and targeted fines. ${ }^{99}$ Using recent data, he made a compelling argument as to how these features of the justice system created odious and ever-deepening challenges for Black defendants. ${ }^{100}$

During the Small Group Discussion segment of the program, we asked students to discuss the presentations and then write an internet-type review of our legal system. To this end, we provided them with a form modeled after an Airbnb review to complete.

${ }^{99}$ Raff Donelson, Cash Bail and Targeted Fines (Sept. 24, 2020) (recording on file with author).

${ }^{100} I d$. 


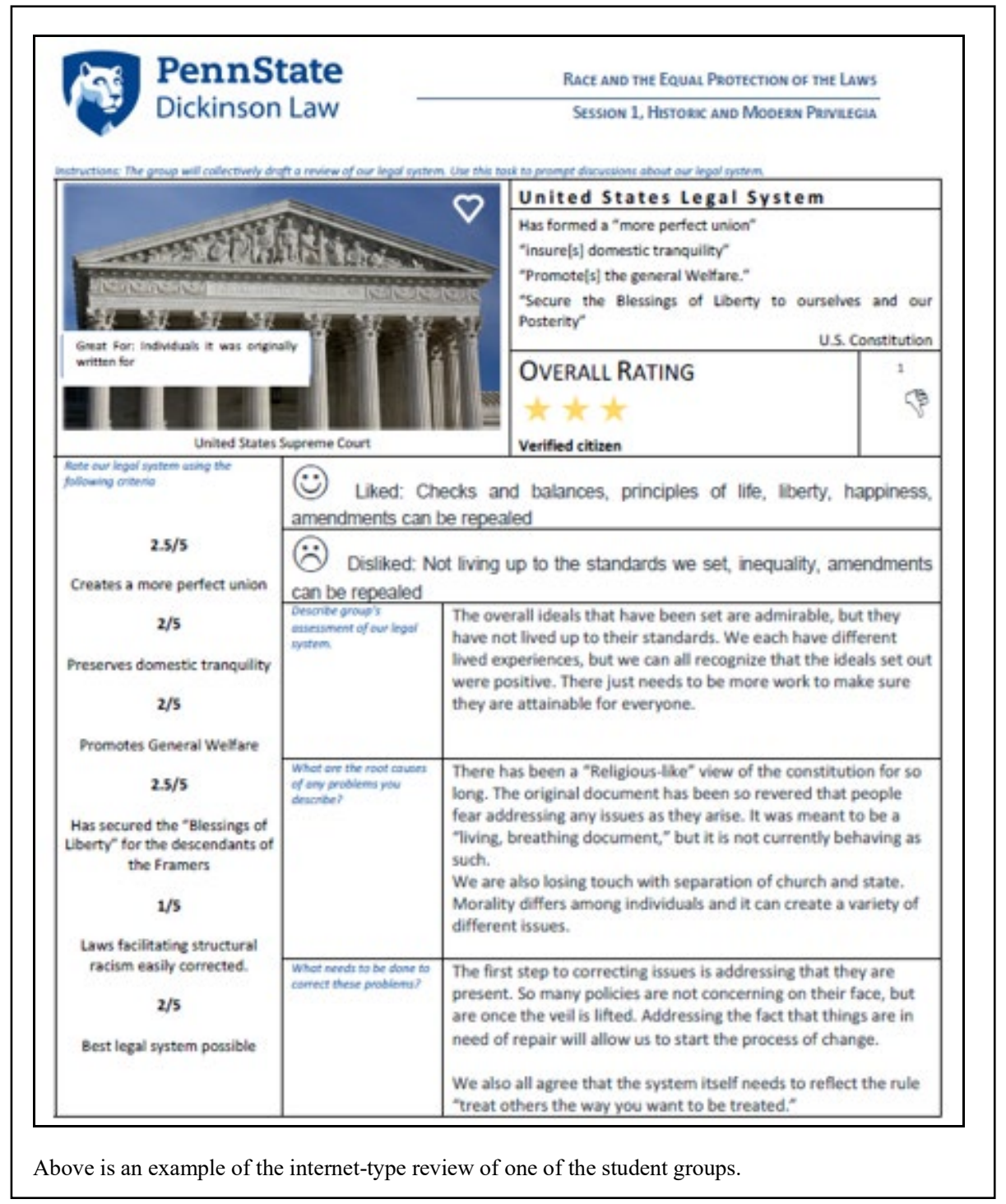

The featured speaker of The Story and Vision segment was the Dean of Dickinson Law, Professor Danielle Conway. Her presentation, entitled "The Duality Between What We Know and What We Should Know About Democracy, Law and the Legal System in America", addressed the embedded duality in our legal system, which is marked by utilitarian approaches to interpretation and application of the law that do not appropriately recognize the role of conscience and morality. ${ }^{101}$ She used the Fugitive Slave Act of 1850 as an example of how the blind application of the law, unbounded by

101 Danielle Conway, The Duality Between What We Know and What We Should Know About Democracy, Law and the Legal System in America (Sept. 24, 2020) (recording on file with author). 
conscience and morality, resulted in the commission of grave crimes against free Black Americans. ${ }^{102}$ The Act incentivized Federal Commissioners, charged with determining whether or not a Black person was a free citizen, to make determinations that forced many free and freed Americans into enslavement. ${ }^{103}$ She described one particular case where a free citizen of nearby Harrisburg was arrested and given over to a southern slave owner pursuant to the Act. It would take the payment of a "ransom" by the community to secure his return. ${ }^{104}$ Dean Conway called for a "new era of Reconstruction", where we as lawyers would acknowledge the persistent dualities in our legal system and "harken" to do what we are called to do as lawyers for the most vulnerable in society. ${ }^{105}$ "We have the platform. The law is a lawyer-driven process - we know the levers to pull in the process" in order to ensure our legal system creates true equality in the lived experience of all Americans. ${ }^{106}$

The accompanying Handout followed a similar format to the session. The Turning Our Attention to the Issue began with John Lewis's last letter, a letter to his fellow citizens and published on the day of his funeral. In "Together You Can Redeem the Soul of Our Nation", Lewis gave his final reflections on the issue of race and his hope in the face of the country's response to the killing of George Floyd. ${ }^{107}$ This section also included a letter by Judge Bernette Joshua Johnson, Chief Justice of the Supreme Court of Louisiana, to her colleagues. In the letter, she shares her reflections on being a Black judge in a system that has perpetrated inequality for so many Black Americans, reminding her colleagues "that laws are not the same as justice." The Handout includes

${ }^{102} \mathrm{Id}$.
${ }^{103} \mathrm{Id}$.
${ }^{104} \mathrm{Id}$.
${ }^{105} \mathrm{Id}$.
${ }^{106} \mathrm{Id}$.

107 John Lewis, Together, You Can Redeem the Soul of Our Nation, THE N.Y. TIMES (July 30, 2020) https://www.nytimes.com/2020/07/30/opinion/john-lewis-civil-rights-america.html. 
essays written by the presenters that more fully set out their presentations and the underlying sources. The Lesson section includes a reprint of the Supreme Court's 1857 decision in Dred Scott v. Sanford.

The section of the Handout devoted to critical reflection begins with Justice Harlan's dissent in Plessy v. Ferguson (1896). It continues the excerpt from Dr. Martin Luther King Jr.'s Letter from Birmingham Jail in which Dr. King addresses how to distinguish between just and unjust laws and how "sometimes a law is just on its face and unjust in its application." 108 John Greiner, a Dickinson Law student, wrote an essay ${ }^{109}$ explaining W.E.B. Du Bois's concept of Double Consciousness and the Veil. ${ }^{110}$

The Story and Vision segment of the Handout began with an essay by Dean Conway on which she based her remarks. It was followed by a passage from Dr. Martin Luther King Jr.'s Where Do We Go from Here: Chaos or Community? In this, his last book, Dr. King sets forth his vision for how we as a country can make progress towards racial justice and equality. He points to the inability of Americans to sustain progress towards racial equality over the long term. Bursts of changes to our laws in response to Selma or Birmingham eventually are overcome by apathy where "the recording of the law in itself is treated as the reality of the reform." 111

${ }^{108}$ DR. MARTIN LUTHER King JR., LETTER FROM BIRMINGHAM JAIL (Apr. 16, 1963)

109 John Greiner, Double-Consciousness and The Veil (Sept. 24, 2020) (unpublished manuscript) (on file with author).

$110 \mathrm{Du}$ Bois wrote, ““'One feels his twoness, - an American, a Negro; two souls, two thoughts, two unreconciled strivings; two warring ideals in one dark body, whose dogged strength alone keeps it from being torn asunder." See W.E.B Du Bois, Strivings of the Negro People, ThE AtlantIC, Aug. 1897, https://bit.ly/31YYsWf [https://perma.cc/3P4W-9YMC].

111 See Dr. Martin Luther King JR., Where Do We Go From Here: ChaOs or Community? 5 (Harper \& Row 1st ed. 1963). 
Session 2: Race and Capitalism

The second session of the program focused on the intersection of race and our system of American capitalism. As with all sessions in the program, we set out to trace the institution of slavery and its relationship to capitalism and follow that history into the present. This session's playlist included the last speech of Dr. Martin Luther King Jr. on April 3, 1968, given in Memphis the day before his assassination. ${ }^{112}$ The list included several contemporary music performances addressing inequality and exploitation. ${ }^{113}$ The Playlist had a link to an episode of the 1619 podcast, which dealt with the systemic impediments to the ownership of property by Black families going back to the unfulfilled promise of "40 acres and a mule." 114

On the night of the session, we turned our attention to the issue of race and capitalism with the video of an interview of Atlantic journalist Vann Newkirk about his research into how Black farmers were systematically forced off their land through the discriminatory practices of the United States Department of Agriculture. The eightminute video summarizes how discriminatory approval and distribution of farming loans worked to force Black farmers to sell their land to their White neighbors at prices that were grossly under market. ${ }^{115}$

112 Dr. Martin Luther King Jr., Address at the Mason Temple in Memphis, TN (Apr. 3, 1968), https://www.youtube.com/watch?v=zgVrlx68v-0.

113 These performances included: TREY SongZ, 2020 RIOTS: How MANY TIMES (Atlantic Records 2020); Rhiannon Giddens, At the Purchaser's Option (Nonesuch Records 2017); AliCia KeYs, QUEEN OF The Field (PAtsey's Song) (Columbia Records 2013); Pharell Williams \& Jay-Z, EnTREPRENEUR (Sony Music Entertainment 2020).

${ }^{114}$ Nikole Hannah Jones, 1619 Project Episode 5: The Land of Our Fathers, Part I, THE N.Y. TIMES (Oct. 4, 2019), https://www.nytimes.com/2019/10/04/podcasts/1619-slavery-sugar-farm-land.html.

115 John Yang, How Southern Black Farmers Were Forced from Their Land, and Their Heritage, PBS NEws HouR (Aug. 13, 2019, 6:30 PM), https://www.pbs.org/newshour/show/how-southern-black-farmerswere-forced-from-their-land-and-their-heritage. 
Professor Dermot Groome introduced the session with a short history of the development of the financial district of Manhattan as the financial capital of the United States and the world. ${ }^{116}$ He identified the location of New York City's slave market on Wall Street, where slaves were not only bought and sold, but leased out for short periods of work for the benefit of their owners. ${ }^{117}$ Groome pointed out that Wall Street itself was named after a wall built by enslaved Africans. ${ }^{118}$

Professor Mohamed Badissy, a specialist in energy and climate financing, taught students the basics of collateralizing debt obligations to show how this modern financial instrument had deep roots in in the United States' history of slavery. ${ }^{119}$ In our early history, slave mortgages were an important and attractive financial instrument for investors. ${ }^{120}$ It was difficult to secure loans with land or crop mortgages. Land was an inexhaustible and inexpensive commodity, and the value of future crops yields was too unpredictable. ${ }^{121}$ Slaves, however, could be used to secure debt because they were prime assets and held their value. ${ }^{122}$ This collateralization of human life was not limited to southern investors; abolitionist-minded northerners and European investors looked at slave mortgages as an attractive and safe investment. ${ }^{123}$ Slave owners could "bundle" slaves of different genders and ages into asset pools that could then be used to secure loans. ${ }^{124}$ The loan could then be used to buy more slaves, which were subsequently

${ }^{116}$ Dermot M. Groome, Introduction (Oct. 29, 2020) (recording on file with author).

${ }^{117} I d$.

${ }^{118} I d$.

${ }^{119}$ Mohamed Badissy, Slavery and Secured Interests (Oct. 29, 2020) (recording on file with author).

${ }^{120} I d$.

${ }^{121} I d$.

${ }^{122} I d$.

${ }^{123} I d$.

${ }^{124} I d$. 
pooled to secure new loans. ${ }^{125}$ This dependable mechanism for creating wealth helped slave owners exploit their slaves in ways far beyond their forced labor. ${ }^{126}$

Kendra Eden, a second-year student, addressed General Sherman's promise to slaves of "40 acres and a mule" and President Andrew Johnson's subsequent withdrawal of that promise. ${ }^{127}$ Ryan Marr examined F.D.R.'s New Deal and explained how it helped lift many White Americans onto a path of financial security and home ownership but embedded racial segregation in communities and created a system of coerced ghettoization of the Black community. ${ }^{128}$ Samantha Jacques spoke about how slaveowning families were able to hold onto and bequeath the wealth earned by the exploitation of enslaved peoples through the generations since slavery. ${ }^{129}$ She talked about the long-term financial consequences of the legal impediments that prevented freed Blacks from receiving patents for their discoveries and inventions. ${ }^{130}$ Particularly, Ms. Jacques spotlighted the inability of Nathan Green and his progeny to receive any benefit from his development of a recipe for a famous type of bourbon whiskey known today as Jack Daniels. ${ }^{131}$

Professor Samantha Prince, who works extensively with small entrepreneurs, addressed the inequities of the Payroll Protection Program (PPP) designed to help such entrepreneurs survive the pandemic. ${ }^{132}$ Prince then spoke more broadly about the

${ }^{125} I d$.

${ }^{126} I d$.

${ }^{127}$ Kendra Eden, A Brief History of “40 Acres and a Mule” (Oct. 29, 2020) (recording on file with author).

${ }^{128}$ Ryan Marr, The New Deal and the Houses Racism Built (Oct. 29, 2020) (recording on file with author).

129 Samantha Jacques, The Backbone of the American Economy (Oct. 29, 2020) (recording on file with author).

${ }^{130} I d$.

${ }^{131} I d$.

132 Samantha Prince, Challenges for Black Entrepreneurs (Oct. 29, 2020) (recording on file with author). 
systemic challenges Black entrepreneurs have in accessing capital. ${ }^{133}$ Deborah Osborn, a second-year student, addressed such impediments in the context of agriculture, ${ }^{134}$ and Professor Laura Williams addressed the inaccessibility of home mortgages for many Black families. ${ }^{135}$

For the small group discussion, students were presented with a hypothetical scenario in which they represented a White client in a contract negotiation with a Black entrepreneur. In the scenario, they identified a way that their client could exploit the structural disadvantages that the Black entrepreneur faced in accessing capital. Their task was to discuss their obligation as attorneys and whether they could or should advise their client to exploit structural racism to gain an advantage. The prompt precipitated a robust discussion, and several of the groups felt that codes of professional conduct should directly address similar situations.

The featured speaker for the Story and Vision segment of the program was Mr. Karl Singleton, the President and founder of the Pennsylvania Diversity Coalition - an organization established to help minority business owners access capital and bid on publicly tendered contracts. The coalition also helps minority business owners develop their skills and talents. Mr. Singleton addressed the COVID-19 pandemic and the difficulties that Black business owners face in accessing PPP loans. ${ }^{136}$ Banks that had welcomed the business that Blacks brought them were suddenly confronted by resistance when it came to applying for PPP loans. ${ }^{137} \mathrm{Mr}$. Singleton challenged students to reconceptualize their roles as lawyers, imploring them to respond to the racial inequities they would undoubtedly encounter with fidelity to the principles of equal treatment under

${ }^{133} I d$.

${ }^{134}$ Deborah Osborn, Black Farmers and Access to Capital (Oct. 29, 2020) (recording on file with author).

135 Laura Williams, Fair Housing, Redlining and the Community Reinvestment Act (Oct. 29, 2020) (recording on file with author).

${ }^{136}$ Karl Singleton, Black Equity and US Capitalism (Oct. 29, 2020) (recording on file with author).

${ }^{137} I d$. 
the law. ${ }^{138} \mathrm{He}$ invited students to work with his organization on projects to help Blackowned business compete on a level playing field. ${ }^{139}$

The Capitalism Handout supplemented the session. It began with an article in which a number of people share their stories of trying to access banking services as Black men. One bank even called the police when one man tried to cash his paycheck. The Dickinson Law presenters each supplemented their presentation with a more detailed essay that included footnotes and suggestions of additional resources for students. The Handout included detailed reporting by David Leonhart from the New York Times and his investigation of the wealth gap between Black and White families from the 1950s to the present. ${ }^{140}$

One of the objectives of the program is to introduce students to the field of Critical Race Theory (CRT) and to provide them with the necessary knowledge and skills to recognize structural racism and develop strategies as lawyers to combat it. We began this process in this handout, in which we introduced students to the work of Derrick Bell, Richard Delgado, Lani Guinier, Angela Harris, Angela Onwuachi-Willig, Patricia Williams, and others. While the program is not designed to provide in-depth coverage of CRT, it values introducing students to concepts like interest-convergence, racial hierarchies and intersectionality.

In an effort to create an academic environment where all ideas can be discussed vigorously yet respectfully, the Handout included a critique of the New York Times 1619 project that asserted the work was inaccurate in several significant ways.

${ }^{138} I d$.

${ }^{139} I d$.

140 David Leonhart, The Black and White Gap Is as Big as It Was in 1950, THE N.Y. TIMES (June 25, 2020), https:/www.nytimes.com/2020/06/25/opinion/sunday/race-wage-gap.html. 
Session 3: Race and Criminal Justice

The pre-session Playlist included a series of podcasts, interviews, and media items related to policing, the criminal justice system, and American prisons. ${ }^{141}$ One short video depicted Black parents discussing "the talk" they give to their children regarding how they should interact with police officers. ${ }^{142}$

For our Turning our Attention to the Issue segment of the program, a Black second-year student volunteered to talk about an encounter he had with the police when he was eight years old. ${ }^{143}$ Shortly after moving to a new neighborhood in Queens, New York with his family, he and his older brother went to shoot baskets at a small park across the boulevard near his home. ${ }^{144}$ While playing basketball, a police car stopped by the park, and after a short conversation about who they were, the police handcuffed his brother and took him away. ${ }^{145}$ The 8 -year-old, frightened and fearing for his brother's

141 These included: A BBC article entitled Former Prisoner Fighting for US Criminal Justice Reform, BBC NEws (Sept. 10, 2020), https://www.bbc.com/news/av/world-us-canada-54105476; An "Opening Statement" given by Paul Butler, Professor at Georgetown Law, in the "trial" of officers who killed Breonna Taylor (Available at: https://twitter.com/georgetownlaw/status/1299338177866616833?lang=en; A slam poem by Javon Johnson, “Cuz he's Black" (2013) (Available at: https://www.youtube.com/watch?v=u9Wf8y_5Yn4); Jarrett Adams, Wrongfully Convicted at 17, Discusses Criminal Justice System (Available at: https://www.youtube.com/watch?v=dUk5BkPfavw); Why We Fight: How You Gonna Reform A Cop? (2006) (Available at: https://www.youtube.com/watch?v=I5zQbdaI_MY\&t=8s); John Oliver monologue on police (June 8, 2020) (Available at: https://www.youtube.com/watch?v=Wf4cea5oObY); and Trevor Noah on George Floyd (May 29, 2020) (Available at: https://www.youtube.com/watch?v=v4amCfVbA_c).

142 Erica Gunderson, Having 'The Talk': How Families Prepare Black Children for Police Interactions, WTTW (June 8, 2020, 8:55 PM), https://news.wttw.com/2020/06/08/having-talk-how-families-prepareblack-children-police-interactions.

143 [name withheld for privacy], Introduction and Turning Our Attention to the Issue (Nov. 11, 2020) (recording on file with author).

${ }^{144} I d$.

${ }^{145} I d$. 
safety, ran home to tell his mother. ${ }^{146}$ It would take several hours before the family could reunite with his brother and secure his release. ${ }^{147}$ They were given a vague explanation that there had been burglaries in the neighborhood and the boy fit the description. ${ }^{148}$ The student subsequently learned that the boulevard they crossed marked an invisible boundary between a White and an integrated neighborhood. ${ }^{149}$ Although only a few hundred yards from their new home, they had inadvertently crossed a boundary into a place where they did not belong. ${ }^{150}$ The student described how the event changed his brother; his formerly outgoing, carefree companion became reclusive, less interested in leaving the house. ${ }^{151}$ The student also talked about how the event changed him, as well as his lasting fear of interactions with police officers. ${ }^{152}$

The Lesson portion of the Session again consisted of short presentations on the relationship between race and the criminal justice system. Professor Gildin and secondyear student Parham Golestanian gave a joint presentation on "Testing the Tests" that examined the "Stop and Frisk" practices of police departments and how the Fourth Amendment tests used by the Supreme Court to assess such stops fail to provide equal protection to citizens of all races. ${ }^{153}$ Professor Katherine Pearson, who earlier in her career was Chief of the Civil Rights Division for the city of Albuquerque, spoke of her experience representing police officers accused of civil rights violations and excessive author).
} 
force. ${ }^{154}$ She addressed the U.S. Department of Justice's investigation of the Albuquerque Police Department and the court-approved settlement that created an independent monitor of the police. ${ }^{155}$

Retired Federal Judge Thomas Vanaskie posed the question of whether those who administer justice adequately reflect the communities they serve. ${ }^{156} \mathrm{He}$ provided several personal accounts of Black defendants frustrated by a judicial process that, in their view, was unfairly and overwhelmingly White. ${ }^{157}$ Professor Thomas Place then gave a presentation on how peremptory challenges in jury selection have, despite clear directives from the Supreme Court, persisted as a mechanism used by some District Attorneys' offices to systematically exclude Blacks from juries. ${ }^{158}$ Professor Raff Donelson addressed the students on the use of fines and their disparate impact on minority communities, ${ }^{159}$ and second-year student Adriana Dunn examined the increasing use of forced labor in our mass incarceration system, particularly in privately-run prisons. ${ }^{160}$ The Lesson segment of the evening concluded with second-year student Aaron Holland reviewing the literature on the disparate impact of the death penalty ${ }^{161}$ and second-year student John Greiner summarizing the First Step Act of 2018. ${ }^{162}$

154 Katherine C. Pearson, Representing Police Charged with Civil Rights Violations (Nov. 11, 2020) (recording on file with author).

${ }^{155} \mathrm{Id}$.

156 Thomas Vanskie, Do Those Who Administer Justice Adequately Reflect the Communities They Serve? (Nov. 11, 2020) (recording on file with author).

${ }^{157} \mathrm{Id}$.

158 Thomas Place, Biased Batson: The Failure of Peremptory Challenge Reform (Nov. 11, 2020) (recording on file with author).

${ }^{159}$ Adrianna Dunn, Mass Incarceration and Forced Labor (Nov. 11, 2020) (recording on file with author).

${ }^{160}$ Raff Donelson, Fines in Criminal Cases (Nov. 11, 2020) (recording on file with author).

${ }^{161}$ Aaron Holland, Disparity in Capital Punishment (Nov. 11, 2020) (recording on file with author).

162 John Greiner, A Look at the First Step Act (Nov. 11, 2020) (recording on file with author). 
During the small group discussions, students engaged one another in the important questions raised in The Lesson and were challenged to consider ways that they as lawyers could make the criminal justice system more just.

The featured speaker for the Story and Vision segment was Mr. Brandon Flood, the Secretary of the Pennsylvania Board of Pardons. Prior to being appointed to the Board of Pardons, Secretary Flood was a legislative assistant and the Executive Director of the Pennsylvania Legislative Black Caucus. ${ }^{163}$ Much of his work focused on reforming our criminal justice system. ${ }^{164}$ Secretary Flood addressed the students on what he saw as the way to reform our criminal justice system. ${ }^{165}$ Flood included his own personal story in his remarks to the students. As a young man, he was arrested on drug and weapons charges on several occasions and spent over nine years as an incarcerated prisoner. ${ }^{166} \mathrm{He}$ described his path from being a subject of our criminal justice system to one of our country's foremost advocates for reform. ${ }^{167}$

As in other sessions, the Handout included essays authored by the students and faculty who gave presentations. The first item was a reprinted article from the New York Times that catalogued the many cases of deaths in police custody where the victims pleaded "I can't breathe." 168 It included a story about the increasing use of artificial intelligence and algorithms to identify offenders and their high error rate when used to

${ }^{163}$ Brandon Flood, Our Criminal Justice System: My Story and Perspective (Nov. 11, 2020) (recording on file with author).

${ }^{164} I d$.

${ }^{165} I d$.

${ }^{166} I d$.

${ }^{167} I d$.

168 Mike Baker, Jennifer Valentino-DeVries, Manny Fernandez \& Michael LaForgia, Three Words. 70 Cases. The Tragic History of 'I Can't Breathe, THE N.Y. TIMES (June 29, 2020), https:/www.nytimes.com/interactive/2020/06/28/us/i-cant-breathe-police-arrest.html. 
identify Black perpetrators. ${ }^{169}$ Professor Donelson contributed an essay on the disparate impact of cash bail. ${ }^{170}$ Also included was an excerpt from a report on the history of mass incarceration by the Brennan Center for Justice. ${ }^{171}$

The Handouts and PowerPoints used in the course contain an image of Jack, an enslaved man. The image was taken by Joseph Zealy for a discredited eugenics study by Harvard Professor Louis Agassiz. The image was chosen because of its high resolution; it captures a dignified man staring directly into a camera used to objectify him. Professor Groome wrote an essay to place the image in context and to inform students of what we know about Jack's life and Agassiz's racist study. ${ }^{172}$

The Story and Vision portion of the Handout included an Op-ed written by former Dickinson Law professor Tiffany Jeffers - now at Georgetown Law. In the piece, Professor Jeffers talks about the conflicts she faces as a former prosecutor and law professor: "I find myself vacillating between two realities. First, recognizing that our legal system was built on the dehumanization of an entire race, making it incapable of ever achieving its true potential. Second, appreciating the brilliance and ingenuity of the American rule of law, and believing that if implemented with care, it can do more good than harm." 173

169 Kashmir Hill, Wrongfully Accused by an Algorithm, THE N.Y. TIMES (June 24, 2020), https://www.nytimes.com/2020/06/24/technology/facial-recognition-arrest.html.

${ }^{170}$ Raff Donelson, A Primer on Cash Bail in the US (Nov. 11, 2020) (unpublished manuscript) (on file with author).

171 James Cullen, The History of Mass Incarceration, BRENNAN CTR. FOR JUST. (July 20, 2018), https://www.brennancenter.org/our-work/analysis-opinion/history-mass-incarceration.

${ }^{172}$ Dermot M. Groome, Jack (Nov. 11, 2020) (unpublished manuscript) (on file with author).

173 Tiffany Jeffers, As a Black Female Law Professor, I'm Nurturing a System that Doesn't Protect People

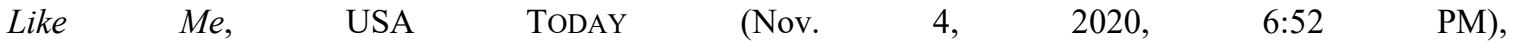
https://www.usatoday.com/story/opinion/policing/2020/11/04/black-female-law-professor-im-nurturingsystem-abandons-me-column/6161526002/. 
Session 4: Race and Housing

The pre-session Playlist included a selection of podcasts and videos to help students prepare for the session. ${ }^{174}$ It also included links to music like Marvin Gaye's Inner City Blues (Make Me Wanna Holler). ${ }^{175}$

To turn our attention to the issue, we played a short video produced by National Public Radio that told the story of housing segregation and redlining in America. ${ }^{176}$ In the video, Gene Demby demonstrates how the National Housing Act of 1934 and the Home Owner's Loan Corporation established a system of segregated housing that still exists today.

In every session, we try to show the continuum between slavery and systems of inequality that still exist today. For this session, students Samantha Jacques and Deborah Osborn presented on the Freedman's Bureau and History of Public Housing respectively. ${ }^{177}$ Professor Sarah Williams gave a thought-provoking presentation on the Great Migration and imagined the tectonic shift in our political landscape that would

174 Richard Rothstein, The Color of Law, a 'Forgotten History' of How the U.S. Government Segregated America, NPR FRESH AIR (May 3, 2017), https://www.npr.org/2017/05/03/526655831/a-forgotten-historyof-how-the-u-s-government-segregated-america; The Color of Law, C-SPAN (May 11, 2017), https://www.c-span.org/video/?428341-1/the-color-law; TPT Originals, Jim Crow of the North - FullLength Documentary, YouTUBE (Feb. 25, 2019), https://www.youtube.com/watch?v=XWQfDbbQv9E; Orion Sun, Orion Sun - Lightning [Official Video], YOUTUBE (Mar. 13, 2020), https:/www.youtube.com/watch?v=He4iTmasOXs; and 50cent, Levittown, InsTAGRAM (Dec. 16, 2020), https://www.instagram.com/tv/CI3GfBVHvwU/?igshid=1breveqlfv049.

175 Marvin Gaye, Inner City Blues (Make Me Wanna Holler), YouTuBE (Jan. 21, 2021), https://www.youtube.com/watch?v=JIExBwFSCJ4.

176 NPR, Housing Segregation and Redlining in America: A Short History, YouTuBE (Apr. 11, 2018), https://www.youtube.com/watch?v=O5FBJyqfoLM\&feature=youtu.be.

${ }^{177}$ Deborah Osborn, History of Public Housing (Jan. 27, 2021) (recording on file with author); Samantha Jacques, The Freedman's Bureau (Jan. 27, 2021) (recording on file with author). 
occur if such a migration were to be reversed. ${ }^{178}$ Second-year student Jacob Kramer presented on the disparate impact of New Deal home ownership credits, ${ }^{179}$ and Professor Alison Lintal brought the presentations into contemporary focus with a careful look at fair housing policy. ${ }^{180}$

In the Lesson segments, we also try to introduce students to the work of renowned Black thinkers. In this session, second-year student Ryan Marr summarized James Baldwin's work on the duality of the American legal system. ${ }^{181}$

During the discussion groups, we presented students with recent census data for Carlisle, the town in which Dickinson Law is located, and challenged them to develop a ten-year plan that would encourage greater integration of its neighborhoods and business districts. Feedback from the group indicated that this prompt precipitated a detailed discussion of presentations and engaged students in a forward-looking conversation about what was possible for the future.

Our featured speaker for the Story and Vision segment was Ms. Kate Walz, a senior staff attorney at the National Housing Law Project. Ms. Walz engages in highimpact litigation on issues related to housing inequality. ${ }^{182}$ Ms. Walz did a masterful job in her dissection of the legal structures in Chicago responsible for establishing and maintaining a system of segregation. Chicago is divided into 50 wards administered by individual Aldermen, who have largely unfettered power to control what happens in their ward through the principle of Aldermanic Prerogative. ${ }^{183}$ They can control whether or not

\footnotetext{
${ }^{178}$ Sarah Williams, Reversing the Great Migration (Jan. 27, 2021) (recording on file with author).

179 Jacob Kramer, New Deal Homeownership Credits (Jan. 27, 2021) (recording on file with author).

${ }^{180}$ Alison Lintal, Fair Housing Policy (Jan. 27, 2021) (recording on file with author).

${ }^{181}$ Ryan Marr, The American Delusion: A Discussion of James Baldwin and Legal Duality (Jan. 27, 2021) (recording on file with author).

182 Kate Walz, A City Fragmented: How Race, Power, and Local Control Shape Chicago's Neighborhoods (Jan. 27, 2021) (recording on file with author).

${ }^{183} I d$.
} 
existing affordable housing is built or maintained, can approve what types of housing can be built, and decide where dangerous materials can be stored or disposed. ${ }^{184} \mathrm{Ms}$. Walz's presentation was a compelling example of how racially neutral laws can be crafted and used to create enduring structures of racist policy. ${ }^{185}$

Ms. Walz also offered students an inspiring personal reflection on how she sees her role as an attorney and framed the role of the lawyer as one of effecting social change in our country. She spoke about Movement Lawyering and how lawyers must see their work as greater than a single lawsuit or a single client:

It is about a radical commitment to advancing racial justice and dismantling systems of oppression. It requires lawyers to confront the legitimate fear in many communities that an attorney will dominate and control the outcome and replicate systems of subordination with which they already struggle and take away from that community their own power and ability to achieve their own success. Movements are led by those facing and most directly experiencing oppression and they are multidimensional - radical demands are welcome as are radical advocacy tools of which lawyers can help, support and develop. ${ }^{186}$

For this session's handout, in addition to a selection of essays and reprints on the issue of race and housing, we included reproductions of the deed for a home with a racial restriction and Shelley v. Kraemer, the Supreme Court case that rendered such restrictions unenforceable. The handout included an essay Isabel Wilkerson wrote for Smithsonian Magazine on the Great Migration, ${ }^{187}$ an essay W.E.B. Du Bois wrote for The Atlantic in

\footnotetext{
${ }^{184} I d$.

${ }^{185} I d$.

${ }^{186} I d$.

${ }^{187}$ Isabel Wilkerson, The Long-Lasting Legacy of the Great Migration, SMITHSONIAN MAG. (Sept. 2016), https://www.smithsonianmag.com/history/long-lasting-legacy-great-migration-180960118/.
} 
1901 on the Freedman's Bureau, ${ }^{188}$ and an interesting piece on how New York's efforts to integrate affordable and luxury accommodation in Manhattan has given rise to the phenomenon of the "Poor Door" - a separate entrance for less affluent and often Black and Brown residents to use. ${ }^{189}$ The Handout ended with a report of an innovative program adopted by Evanston, Illinois to use revenue from the sale of legalized marijuana to help create a reparation fund. ${ }^{190}$ Finally, broadening our effort to introduce students to the work of Black scholars and thinkers, we included a detailed obituary of Hank Aaron, who died just prior to the session. The piece describes in detail, his life, his accomplishments, his struggle for racial equity and his great contribution to American life. ${ }^{191}$

Session 5: Race and Health Care

The pre-session Playlist included a variety of podcasts and videos to introduce the long history of race and health care in the U.S. These ranged from a piece on the

${ }^{188}$ W. E. B. Du Bois, The Freedmen's Bureau, THE AtLANTIC (March 1901).

${ }^{189}$ Mireya Navarro, 'Poor Door' in a New York Tower Opens a Fight over Affordable Housing, THE N.Y. TIMES (Aug. 26, 2014), https://www.nytimes.com/2014/08/27/nyregion/separate-entryways-for-new-yorkcondo-buyers-and-renters-create-an-affordable-housing-dilemma.html.

190 Andy Fies, Evanston, Illinois, Finds Innovative Solution to Funding Reparations: Marijuana Sales Taxes, ABC NEWS (Jul. 19, 2020), https://abcnews.go.com/US/evanston-illinois-finds-innovative-solutionfunding-reparations-marijuana/story?id=71826707.

${ }^{191}$ David Waldstein, 'A Great Friend, a Great American and a Great Player', THE N.Y. TIMES (Jan. 31, 2021), $\quad$ https://www.nytimes.com/2021/01/22/sports/baseball/hank-aaron-deathreaction.html?searchResultPosition=1. 
Tuskegee syphilis experiment ${ }^{192}$ to modern race-based inequality in our health care system. ${ }^{193}$

The Turning our Attention to the Issue segment was a CNN report on the death of Susan Moore, M.D., from COVID-19; Dr. Moore had reported biased treatment when she was hospitalized for COVID-19. ${ }^{194}$ Despite her protestations, she was denied care she knew as a doctor was medically necessary. ${ }^{195}$ She was discharged only to be readmitted to a different hospital where she ultimately died. ${ }^{196}$

During this, our fifth session, some first-year students in the class asked if they could begin participating in designing and delivering the program. We began The Lesson segment with a contribution by first-year student Shila Bayor on the impact of COVID19 on Black and Brown communities. ${ }^{197}$ Bayor's presentation was followed by that of Professor Emily Michiko Morris, who gave a presentation on Race and Medical Research. ${ }^{198}$ Professor Morris sketched out the sad timeline of the unethical use of Black subjects in medical research. ${ }^{199}$ Professor Medha Makhlouf, the Director of Dickinson

192 Univ. of Minn. Sch. of Pub. Health, S2E4: Racism \& Public Health: Tuskegee to COVID-19 (Dec. 8, 2020), https://www.youtube.com/watch?v=ATjKqB0cWqQ.

193 Christen Linke Young, There Are Clear, Race-Based Inequalities in Health Insurance and Health Outcomes, BROOKINGS INST. (Feb. 19, 2020), https://www.brookings.edu/blog/usc-brookings-schaeffer-onhealth-policy/2020/02/19/there-are-clear-race-based-inequalities-in-health-insurance-and-health-outcomes/.

194 Dakin Andone, A Black Doctor Died of Covid-19 Weeks After Accusing Hospital Staff of Racist Treatment, CNN (Dec. 25, 2020, 7:33 AM), https://www.cnn.com/2020/12/24/us/black-doctor-susanmoore-covid-19/index.html.

${ }^{195} I d$.

${ }^{196} I d$.

197 Dermot M. Groome \& Shila Bayor, Race and Health Care: Introduction (Feb. 17, 2021) (recording on file with author).

${ }^{198}$ Emily Michiko Morris, Racism and Medical Research (Feb. 17, 2021) (recording on file with author). ${ }^{199} I d$. 
Law's Medical-Legal Partnership Clinic, gave a presentation on the social determinants of health and how a range of structural inequalities contribute to disparate health outcomes. ${ }^{200}$ Second-year student Parham Golestanian gathered the most current data to demonstrate the differential treatment of Blacks within our healthcare system. ${ }^{201}$

Dickinson Law Alumni have asked to be involved in this program, and Alumna Crystal Edwards, an experienced health law attorney, gave students a presentation on accessing health care through the Medicaid system. ${ }^{202}$ Finally, Professor William Wenner, who teaches Health Law, framed health care as a fundamental human right. ${ }^{203}$ He examined some of the international human rights conventions ratified by the United States to make the case that this country has an international legal obligation to provide more comprehensive health care that is equally accessible to all Americans. ${ }^{204}$

The small group prompt asked students to consider the relationship between universal health care and race. The prompt was from a book by the Featured Speaker for the session, Dr. Khiara M. Bridges, a professor at UC Berkeley School of Law. Among Professor Bridges's scholarly works is her 2019 book Critical Race Theory: A Primer. Professor Bridges challenged students to examine health care from the perspective of race. ${ }^{205}$ She recounted a study that she performed in New York City, in which she examined health care outcomes of two hospitals located within a few hundred feet of

\footnotetext{
${ }^{200}$ Medha Makhlouf, Social Determinants of Health (Feb. 17, 2021) (recording on file with author).

201 Parham Golestanian, Differential Treatment of Blacks in the Health Care System (Feb. 17, 2021) (recording on file with author).

202 Crystal Edwards, Accessing Health Care: The Medicaid System (Feb. 17, 2021) (recording on file with author).

${ }^{203}$ William Wenner, Health Care Justice (Feb. 17, 2021) (recording on file with author).

${ }^{204} I d$.

205 Khiara Bridges, Explaining Racial Disparities in Health: The Limitations of Implicit Bias (Feb. 17, 2021) (recording on file with author)
} 
each other. ${ }^{206}$ One was public and underfunded; the other was a private, well-funded hospital that catered to patients with good health insurance. ${ }^{207}$ Both hospitals were in large part served by the same group of medical interns. ${ }^{208}$ Professor Bridges posited that the significant difference between the health care outcomes of the hospitals' patients was attributable to the quantity and quality of each hospital's supply of medical technology. ${ }^{209}$

This session's Handout began with the story of the "disease" Drapetomania, the existence of which Dr. Samuel A. Cartwright posited in 1851. Cartwright claimed to have discovered the psychiatric disorder that made enslaved African-Americans want to escape slavery. ${ }^{210}$ Once again, the Handout included essays by Dickinson Law students and faculty $^{211}$ as well as reprints of essays related to race and our health care system. ${ }^{212}$ The Handout contained the excerpt of a speech Dr. King gave to the American Medical

${ }^{206} I d$.

${ }^{207} I d$.

${ }^{208} I d$.

${ }^{209} I d$.

${ }^{210}$ Michael Coard, Drapetomania: Compliant Blacks Sane, Resisting Blacks Insane, PHILA. TRIB. (Mar. 2019).

211 These contributions included Professor Medha D. Makhlouf's Addressing Racism Through MedicalLegal Partnerships, second-year student's Deborah Osborn's Representation in the Healthcare Professions, and second-year student Parham Golestanian's Differential Medical Treatment and Health Outcomes for Minority Groups and its Effects Amid a Pandemic.

212 See e.g., Sheri Fink, Dying of Covid in a 'Separate and Unequal' L.A. Hospital, THE N.Y. TIMES (Feb. 16, 2021), $\quad$ https://www.nytimes.com/2021/02/08/us/covid-los-angeles.html?searchResultPosition=1; Health Equity Considerations and Racial and Ethnic Minority Groups, CTRS. FOR DISEASE CONTROL \& PREVENTION (Feb. 12, 2021), https:/www.cdc.gov/coronavirus/2019-ncov/community/health-equity/raceethnicity.html; Valerie Kennedy, Do Black Lives Matter to Big Pharma? - It's Time for Companies to Confront Racial Bias in R\&D and Health Care, MEDIUM (June 21, 2020), https://medium.com/@kennedyesq516/do-black-lives-matter-to-big-pharma-9edf8c7aeddb. 
Association in which he said: "We are concerned about the constant use of federal funds to support this most notorious expression of segregation. Of all the forms of inequality, injustice in health is the most shocking and the most inhuman because it often results in physical death." 213

Session 6: Race and Education

The pre-session Playlist for Race and Education included a variety of podcasts and videos that addressed racial disparities at all levels of education. ${ }^{214}$ This session coincided with an upsurge of unprovoked attacks on Asian Americans in the country. We invited Minh Le, a 1L student from Viet Nam to share his perspective on these events as an Asian American. ${ }^{215}$

To turn the students to the generative theme of education we played a video of a recent interview of Ruby Bridges, the six-year-old girl who was accompanied by U.S. Marshals to school because of threats to her life by people who did not want a black child in school with their children. ${ }^{216}$

The Lesson segment began with a lecture by Professor Lucy Johnston-Walsh about the Carlisle Indian Industrial School located in the same town as Dickinson Law and now the home of the U.S. Army War College. Professor Johnston-Walsh described how the school with its motto "Kill the Indian, Save the Man" took indigenous children from their families, stripped them of their culture and attempted to indoctrinate them in

\footnotetext{
${ }^{213}$ Dan Munro, The 50th Anniversary of Dr. King's Healthcare Quote, ForBES (Mar. 25, 2016, 12:01 AM), https://www.forbes.com/sites/danmunro/2016/03/25/the-50th-anniversary-of-dr-kings-healthcarequote $/$ sh $=59 \mathrm{ce} 471 \mathrm{~b} 30 \mathrm{~b} 5$

${ }^{214}$ Mary Anne Wolf, The Color of Education, EdUCATION MATTERS (Oct. 12, 2020) https://www.ednc.org/perspective-the-intersection-of-race-equity-and-education/; Shaun Harper, We Need to Talk about Race and Higher Education, AMERICAN COUNCIL ON EDUCATION, RACE AND ETHNICITY IN HIGHER EDUCATION, https://www.equityinhighered.org/resources/ideas-and-insights/we-need-to-talkabout-race-in-higher-education/; Andrew Cohen, Berkeley Conversations: Race, Law and Education, BERKELEY NEWS (Sept. 14, 2020) https://news.berkeley.edu/2020/09/14/race-law-and-education/

${ }^{215}$ Minh Le (Eric), Violence against Asian Americans (Mar. 17, 2021) (recording on file with author).

${ }^{216}$ Goalcast, Ruby Bridges Fought Racism at Six Years Old (Nov. 4, 2020) https://www.youtube.com/watch?app=desktop\&v=UKVv8NH6YGk
} 
the ways of Euro-centric life. ${ }^{217}$ Professor Jeffrey Dodge examined the legacy of Brown v. Board of Education and how oversight mechanisms have weakened over the years. ${ }^{218}$ Upper-level students gave presentations on busing, the discriminatory impacts of magnet and charter schools, racial disparities in education, bias in standardized testing and the over-policing of black students. ${ }^{219}$ The Lesson segment ended with Professor Dwayne Kwaysee Wright, a visiting professor at George Washington Graduate School of Education providing a lecture on Education from a Critical Race perspective. ${ }^{220}$

The prompt for the small group discussions was two-fold. Students were first invited to share their assessment of their own primary education experience and identify the factors that positively or negatively impacted that experience. Second, they were to imagine that the Biden administration had charged their group with coming up with one impactful idea that would foster high quality education that is equally accessible to all Americans.

The featured speaker for this session was Preston Green III, the Neag Professor of Urban Education at the University of Connecticut Neag School of Education. He began his remarks recounting an experience he had as a youngster when his family moved. When he entered his new school and without any aptitude testing he was placed in a class of low achieving students. It would take advocacy on his own part and the part of his parents before he was placed in a class appropriate to his aptitude and educational needs. When he was ultimately tested, he was moved into the program for gifted students. ${ }^{221}$ Professor Green spoke about his scholarly work regarding racial disparities in school

\footnotetext{
217 Lucy Johnston-Walsh, The Carlisle Indian Industrial School (Mar. 17, 2021) (recording on file with author).

218 Jeffrey Dodge, Brown v. Board of Education Today (Mar. 17, 2021) (recording on file with author).

219 John Greiner, Busing; Rachel Wilcove, Contemporary Mechanism of De Facto Segregation: Title I vs. Charter and Magnet School; Parham Golestanian, Disparities in Education; Kendra Eden, Bias in Standardized Testing, College Admission, \& Present-Day Segregation in Schools; and Deborah Osborn, Over-Policing of Black Students (Mar. 17, 2021) (recording on file with author).

220 Dwayne Kwaysee Wright, Education: A Critical Race Perspective (Mar. 17, 2021) (recording on file with author).

221 Preston Green III, Black-White School Funding Disparities: Their Causes and Solutions (Mar. 17, 2021) (recording on file with author).
} 
funding and shared his own path to using his training as a lawyer and his interest in education to work for greater equality in our country's education system. ${ }^{222}$

The handout for the session included essays written by the presenters and reprinted articles that amplified the themes addressed in the session.

${ }^{222}$ Id.

DRAFT - DO NOT CITE $\quad 63$ of 71 
Session 7: Race and Democracy

The pre-session Playlist for the session on Race and Democracy included a variety of materials related to voting. ${ }^{223}$ The session opened with the "Turning our Attention to the Issue" segment by playing a video on the history of women's suffrage and why voting is such an essential part of our democracy. ${ }^{224}$ In keeping with REPL's practice of encouraging student involvement in the creation and delivery of this program 1L Taylor Haberle, described his work on political campaigns and shared his perspective on democracy and potential threats to it. ${ }^{225}$ Another 1L student Jeremy Garcia, opened the Lesson segment of the session with an overview of Judge Tom Bingham's highly regarded book, The Rule of Law and its exegesis of the core principles constituent to the concept of the rule of law. ${ }^{226}$ This was followed by a presentation by Dean Danielle Conway that explored the rule of law in the context of and in relation to race. ${ }^{227}$ Professor Laurel Terry, whose scholarly work focuses, in part, on the legal profession, gave a presentation entitled "Who is at the Table of our Democracy?" which examined our branches of government, their respective levels of diversity and the implications that a

\footnotetext{
223 These items included: National Archives, Black Americans and the Vote, AFRICAN AMERICAN HERITAGE https://www.archives.gov/research/african-americans/vote; Ev Andrews, The Voting Rights Act Marks 55 Years. Here's What you Should Know, CNN (Aug. 6, 2020) https://www.cnn.com/ampstories/politics/voting-rights-act-marks-55-years-heres-what-you-should-know; and Martha S. Jones, Vanguard: How Black Women Broke Barriers, Won the Vote, and Insisted on Equality for All (Aug. 26, 2020) https://www.youtube.com/watch?v=elic4pnvy8A

${ }^{224}$ Sarah Elizabeth Adler, Why Women's Right to Vote Matters 100 Years Later, AARP (Aug. 14, 2020) https://www.aarp.org/politics-society/history/info-2020/women-right-to-vote.html.

225 Taylor Haberle, Introduction (Apr. 7, 2021) (recording on file with author).

226 Jeremy Garcia, The Rule of Law (Apr. 7, 2021) (recording on file with author).

${ }^{227}$ Danielle Conway, The Rule of Law, Race, Racism and Equality (Apr. 7, 2021) (recording on file with author).
} 
lack of diversity have on our system of self-governance. ${ }^{228}$ Second year student Ryan Marr gave a presentation on the importance of our national defense and the often unrecognized contribution of African Americans to our military. ${ }^{229}$ Professor Stan Brand, former general counsel to the U.S. House of Representatives and 2L Parham Golestanian gave presentations on the history of legislation impacting the right to vote. ${ }^{230}$ In the final presentation in the Lesson segment Professor Lance Cole, made the argument that the right to vote is about much more than simply casting a ballot. As the central act of participation by citizens it is their way of impacting policy and legislation that affects all aspects of our lives as Americans. Cole recalled the Supreme Court's recognition in the Yick Wo v. Hopkins case that voting is a fundamental right that is "preservative of all rights." 231

The small group discussion was introduced by Adam DeBernardis, a first-year student. The prompt for the discussion asked students to grapple with the polarization that now exists in our political system and in our discourse as citizens about our country and its future. Students were challenged to develop strategies to facilitate more meaningful and purposeful conversations around controversial topics that are respectful. ${ }^{232}$

\footnotetext{
${ }^{228}$ Laurel Terry, Who is At the Table of Democracy (Apr. 7, 2021) (recording on file with author).

${ }^{229}$ Ryan Marr, No Retreat: African American Servicemembers And The Struggle To Fight (Apr. 7, 2021) (recording on file with author).

${ }^{230}$ Parham Golestanian, The History of Voting: Reconstruction to the Civil Rights Act of 1957 and Stan Brand, The Voting Rights Act of 1965 \& Shelby Country v. Holder (Apr. 7, 2021) (recording on file with author).

${ }^{231}$ Lance Cole, The Right to Vote is About More than Voting (Apr. 7, 2021) quoting Yick Wo v. Hopkins, 118 U.S. 356, 370 (1886) (recording on file with author).

232 The prompt provided to the students was:
} 
We were fortunate to have as our speaker for the Story and Vision segment Professor Deborah N. Archer the Jacob Javits Professor at NYU law school and the $8^{\text {th }}$ President of the American Civil Liberties Union. She encouraged students to think broadly about their role in working for equality within our legal system. "[T]he fight for equality is both about attacking the unjust systems but also about influencing the myriad everyday interactions which determine whether subordinated people have real power to affect their futures and to lead choice filled lives." ${ }^{233}$ Archer pointed to our country's continued segregation of living, educational and social spaces as reflective of a system that protects privilege and impedes progress toward a country with greater equality for all Americans. ${ }^{234}$ She expressed her concern at current efforts to restrict the right to vote and placed it in historical context. In addressing what her vision was for the future, she

This evening's lesson focused on American democracy. The drafters of our founding documents held very different views about the form and structure of our democracy. Their views about the rights and obligations of those living on the territory of the proposed country, as well its relationship to independent state governments already in existence, could not have been more polar or deeply entrenched. Sometimes the debates, speeches, arguments, conversations, and discussions were constructive and sometimes less so. But there is an important takeaway ... all these interactions between people continued to occur. The communication continued, whether through writings, lectures, orations, sermons, or heated exchanges. The benefits of that labor are present in the United States Constitution.

What can we do to ensure that we foster conversations that are authentic, meaningful, and purposeful, even if those conversations result in disagreement over process and/or substance? How do we foster a conversational ecosystem that draws you into discussion, debate, and discourse even when you may hold a position counter to that of another person? Importantly, modes of discourse that provide participants an opportunity to be heard, to be critiqued, and to be considered are the pillars of the American democracy.

What are some points that you can propose to build pathways or models for facilitating authentic, meaningful, and purposeful communications around topics that are controversial, provocative, and difficult? In thinking about your response, consider your own amenability to compromise and collective interest.

${ }^{233}$ Deborah N. Archer, Race and Democracy (Apr. 7, 2021) (recording on file with author). 
reaffirmed the call of other civil rights lawyers for the need for a Third Reconstruction to complete the work of the First (post-Civil War Amendments) and Second (Civil Rights Movement of the 1960s). She sees that this Third Reconstruction is necessary in order to address some of the setbacks to racial equality since the Civil Rights Movement and to "address historic and systemic racism, inequality, and to center human dignity and community equity as central to our racial justice and our racial justice agenda."235

Session 8: Using the Law for Change

The first seven sessions of the REPL program each focused on a particular area of the law and explored the relationship between that area and race. From the earliest days of designing the program, I always thought that this final session had to shift focus to the students themselves. If our overall objective, expressed in Race and our Educational Mission resolution was to "cultivate within students, a principled, enduring commitment to work for true equality in our society over the course of their careers," REPL needed to do accomplish two things in this last session. First, to help students begin the process of discerning the type of lawyer they want to become. How will they combine their unique combination of natural talents and abilities, life experience and legal education to make a constructive contribution to the future of our country as lawyers within the chapter of US history that they will occupy? This is obviously a long-term endeavor and we can only hope to encourage students to initiate the process. Second thing we needed to accomplish in this session is to help students form an enduring commitment to equality and racial justice what is tenacious in the face of other professional commitments and personal obligations. How can we help them remember whatever it is that they hope to contribute to our country, in a way that reaffirms their best inclinations and revitalizes their despite the inherent busyness of modern life. We accomplished these goals in the following way. 
For this session, we dispensed with the format of the first seven sessions. To help students begin the process of thoughtful reflection on how their unique set of abilities, life experiences and legal training might come together, we had several presentations about important work that lawyers have done to promote equality as well as a candid assessment about the current state of our legal system and the most promising levers of change at the moment.

We began the session with a presentation by Professor Lucy Johnston-Walsh, director of our Child Advocacy clinic. Professor Johnston-Walsh described her work drafting and advocating for a Pennsylvania law, enacted in 2019, that requires all Pennsylvania universities to give tuition waivers to youth who are in the Commonwealth's foster care system or aged-out of the system. Walsh recognized the educational inequities that children in the foster-care system faced and worked to make a university education possible for them if they chose to pursue one. ${ }^{236}$ She spoke about a current client of the Dickinson Law Child Advocacy Clinic who has begun her studies to become a nurse. Walsh impressed upon students the obligation we have as lawyers to "take the lead from your clients who are directly impacted. Find areas of law and policy that need to be changed." 237

Professor Gary Gildin, who has engaged in Civil Rights litigation for the ACLU gave students a presentation entitled Overview of Litigation Strategies in which he gave his assessment of different litigation strategies and their relative effectiveness in today's legal environment. ${ }^{238}$ Gildin encouraged students to also think more broadly about their work as lawyers and suggested venues other than courts, where they can effectively advocate for change.

Professor Michael Mogill talked about his work for Georgia Legal Aid Services. ${ }^{239} \mathrm{He}$ described the clients he helped and the broad array of urgent life-

${ }^{236}$ Lucy Johnston-Walsh, Using the Law to Change Lives (Apr. 28, 2021) (recording on file with author).

${ }^{237} I d$.

${ }^{238}$ Gary Gildin, Overview of Litigation Strategies (Apr. 28, 2021) (recording on file with author).

${ }^{239}$ Michael Mogill, They Called Me "Legal Aid” (Apr. 28, 2021) (recording on file with author). 
impacting issues that they brough to him. He spoke about his satisfaction making our legal system work for some of the most vulnerable in Georgia. Professor Amy Gaudion placed the role of a lawyer in the context of our civic responsibilities as American citizens. ${ }^{240}$ Professor Gaudion reminded students that the preamble of the ABA Model Rules on Professional Conduct require lawyer's to "further the public's understanding of and confidence in the rule of law and the justice system." 241 Two recent graduates spoke about their work advocating for greater equality in housing and health care. ${ }^{242}$

For this session we invited two outside featured speakers to address the students. Mr. Kent Spriggs, is the author of a highly respected two-volume work on Title VII litigation. Earlier in his career was a lawyer in the Civil Rights Movement. ${ }^{243} \mathrm{He}$ is also the author of Voices of the Civil Rights Lawyers: Reflections from the Deep South, 1964-1980. ${ }^{244}$ Mr. Spriggs talked about his work litigating Civil Rights cases, his motivation for doing so and the satisfaction of doing this work. ${ }^{245}$ The second outside speaker was Ms. Katie Gallagher, a senior lawyer with the Center for Constitutional Rights. Ms. Gallagher talked about impact litigation, how the Center selects cases and what they hope to achieve through such litigation. ${ }^{246}$ I spoke to students about my work as an international criminal prosecutor and relayed a particular case of how a vulnerable traumatized victim was able to confront one of the most violent war criminals in Bosnia during the Yugoslav crisis and give her evidence against him because of her confidence in the international legal system and my ability as a lawyer to guide her through the process. ${ }^{247}$

\footnotetext{
${ }^{240}$ Amy Gaudion, Lawyers and Civic Responsibility (Apr. 28, 2021) (recording on file with author). ${ }^{241} I d$.

${ }^{242}$ Kadeem Morris, My Work for Housing Equity and Marissa LaWall, My Work for Equity in Health Care (Apr. 28, 2021) (recording on file with author).

${ }^{243}$ Kent Spriggs, My Work in Civil Rights (Apr. 28, 2021) (recording on file with author).

${ }^{244}$ Kent Spriggs, Voices of Civil RightS LAWYers: REFLECTIONS FROM THE DEEP SOUTH, 1964-1980 (2017).

${ }^{245} \mathrm{Id}$.

${ }^{246}$ Katie Gallagher, My Work at the Center for Constitutional Rights (Apr. 28, 2021) (recording on file with author).

${ }^{247}$ Dermot Groome, My Work in International Law (Apr. 28, 2021) (recording on file with author).
} 
For the small discussion group in this last session, we invited students to share with each other their emerging sense of what they might contribute to our country as lawyers and what they saw as the opportunities and responsibilities of a lawyer at this moment in our country's history. Over the course of the year, the small groups have consisted of the same members and it was our hope that students had formed bonds of trust with each other. For most groups, this proved to be true and students did begin conversations we hope will continue over the course of their time as law students.

To conclude this session and the program I made a personal observation and suggestion. I described to students how as a law student and young lawyer I read about lawyers I admired and wondered how I might best contribute to my profession and our world. One of the books I read was Mohandis Gandhi's autobiography, The Story of My Experiments with the Truth. In the book, Gandhi writes about his personal development and his work as a lawyer combatting racial persecution in South Africa, his work for Indian independence and advocacy for a more equal society in India. I told them about Gandhi's practice of making personal commitments to himself, promises that bound him to a course of action he was determined to follow. Gandhi used these personal vows as a means of checking his progress towards his goals, his objectives. He would return to them periodically an assess his progress and reinvigorate his commitment to the goal.

In some cases, these promises were about trivial matters such as learning how to ballroom dance to fit in with British society. But in most cases, they were vows of substance and helped him chart a life of purpose and consequence. His most well-known vow was his vow to nonviolent protest, a vow that so inspired Dr. King that he too took a vow to engage in nonviolent protest, a vow that became the cornerstone of the Civil Rights Movement.

I invited students to spend some time over the summer reflecting on the course, the challenges facing our country and the unique contribution they can make as individuals and lawyers to the future of our country. I suggested that they record a video of themselves making the commitment to themselves. Recording themselves would not only require them to verbalize their commitment but memorialize it for future reference. 


\section{Part IV. Conclusion}

Our task as legal educators today is greater than it has been in the past. In this important period of our national history, our country requires of us something that only we can provide: a generation of lawyers who will dismantle the remaining vestiges of systemic racism in our nation. ${ }^{248}$ We must educate the next generation of lawyers to finish the job of rooting out systemic racism wherever it continues to live and breed. We must equip our students not simply with the knowledge and skills they will need for this task but with a sense of their place and role in our changing, imperfect, struggling democracy and with the enduring passion they will need to sustain their efforts.

${ }^{248}$ Vernon Jordan wrote several years ago, "I am of the belief that in order to change a nation you must of course change hearts and minds, but you must also change the laws. And to change the laws you need good lawyers." Vernon E. Jordan Jr., A Celebration of Black Lawyers, Past and Present, THE NEW YORKER (June 7, 2017), https://www.newyorker.com/news/news-desk/a-celebration-of-black-lawyers-past-andpresent. 